\title{
State capitalism in international context: Varieties and variations
}

\section{Mike Wright $^{\mathrm{a}}$, Geoffrey Wood ${ }^{\mathrm{b}}$, Aldo Musacchio ${ }^{\mathrm{c}}$, Ilya Okhmatovskiy ${ }^{\mathrm{d}}$, Anna Grosman ${ }^{\mathrm{e}, *}$, Jonathan P. Doh ${ }^{\mathrm{f}}$}

${ }^{\text {a }}$ Imperial College London, UK

${ }^{\mathrm{b}}$ Western University, UK

${ }^{\mathrm{c}}$ Brandeis University, USA

${ }^{\mathrm{d}}$ Universidade Nova de Lisboa, Portugal

${ }^{\mathrm{e}}$ Loughborough University, UK

${ }^{\mathrm{f}}$ Villanova University, USA

\section{A R T I C L E I N F O}

The Virtual Special Issue on State Capitalism in International Context is posthumously dedicated to Mike Wright (1952-2019) who was the driving force behind the original ideas in the call for proposals, helped shape the overall contribution of the SI, and served as lead editor until his passing in late 2019.We are hugely indebted to him for this issue to come to life. The Virtual Special Issue Editors.

\section{Keywords:}

State capitalism

Statism

Government

State-owned enterprises

International business

State-owned multinationals

Sovereign wealth funds

Political ideology

Political institutions

Internationalization

\begin{abstract}
A B S T R A C T
State interventions in markets assume varieties of forms in different economic systems. To capture this variety, we consider state capitalism as a multidimensional concept, first reviewing its historical evolution from both practical and scholarly vantages. We describe several dimensions of state capitalism and demonstrate how crossnational variations can be captured through positioning countries along these dimensions. We use cross-sectional data for a large sample of countries to derive factors that represent key dimensions of state capitalism. We demonstrate how cross-national and historical variation in state capitalism is captured by this Virtual Special Issue and offer suggestions for future research.
\end{abstract}

"We've never 'trusted' Huawei," said Ian Levy, the technical director of the UK's national cybersecurity centre. You can see that lack of trust in the fact that, uniquely, the government set up the "Huawei Cyber Security Evaluation Centre"... a world-first operation that sees the UK state directly assessing Huawei's capability. That exists, Levy says, "because we treat them differently to other vendors." The Guardian, 2020

\section{Introduction}

The COVID-19 global pandemic has made clear the significant variation in how states respond to crises and how those responses are directly linked to the configuration of state apparatus across countries-for example, whether the health service is state-owned and the degree of state support extended to specific private firms. These observations highlight the importance of understanding the heterogeneity of state capitalism across countries and how effectively government institutions address comprehensive and systemic crises. Yet, the 2020

\footnotetext{
* Corresponding author at: Loughborough University London, 3 Lesney Avenue, Here East, Queen Elizabeth Olympic Park, London E20 3BS, UK.

E-mail address: a.grosman@lboro.ac.uk (A. Grosman).
} 
crisis also raises the question of whether such a large shock can change the configuration of states and the extent of state intervention, as happened following the Great Depression (The Economist, 2020). If this health crisis becomes more protracted or evolves into a long-term economic crisis, more state intervention and an increase in state ownership in the economy is likely, as witnessed in the aftermath of the Global Financial Crisis of 2008-2009 (Lazzarini \& Musacchio, 2020; Megginson \& Fotak, 2020; Reinhart \& Rogoff, 2009).

This Special Issue is focused on understanding the complexity of state capitalism and providing fresh evidence, reflections, and theorizing to better account for variation in how the institutions of state capitalism work both within and between countries and over time, which cannot be synthesized with one political or economic variable. That is why this Special Issue and this introduction advance the argument that in order to understand state capitalism and the performance of state-owned multinationals, we need to unbundle multiple institutional dimensions that explain cross-sectional and longitudinal variation.

Following this multidimensional logic, we define state capitalism as an economic system in which the state uses various tools for proactive intervention in economic production and the functioning of markets. State interventions can occur within the home market and abroad, in the interest of domestic firms and for diplomatic purposes. States may intervene by owning a significant percentage of productive assets through various forms of statism such as government subsidies, investments, consumption, and various regulatory instruments, as well as through formal and informal coordinating mechanisms. These interventions guide economic activity in ways that may or may not challenge the private business. They encompass protection for oligopolistic firms and unconventional monetary policy interventions. Overall, we view state capitalism through the lens of variation, complexity, and multidimensionality, not simply whether a country follows state capitalism or not.

We differentiate state capitalism from economic systems that rely on central forms of command, quotas, and centrally imposed prices (e.g., the USSR before 1989 reforms or China during the Mao Zedong era). Under state capitalism, the means of production are mostly privately owned, and actors and firms use markets and prices as the main coordination mechanisms in the economy. Further, the ultimate effect of state interventions on the private sector is determined by the political goals of the states (e.g., predatory or developmental) as well as by the scale and scope states have for supporting private economic activity and not by a political regime per se.

We conceptualize state capitalism more broadly than previous management scholarship that tends to focus on state ownership and state-controlled capital (Aguilera, Capapé, \& Santiso, 2016; Musacchio, Lazzarini, \& Aguilera, 2015). We include the range of state intervention in the economy through tariffs, subsidies, formal and informal networks, etc., as is common in political science and other social sciences (Alami \& Dixon, 2020; Nölke, 2014; Sallai \& Schnyder, 2020).

In this introduction to the Special Issue, we add our own exploratory analysis of the dimensions that can define the institutional matrix of state capitalism. Using factor analysis with multiple variables, we define three key dimensions of state capitalism: state ownership, statism, and threatening vs. non-threatening government. We use these dimensions to situate different types of state capitalism and broaden the configuration of state capitalist systems. We discuss the national context and cross-national differences in state capitalism models and propose state capitalism categorizations that capture the heterogeneity in forms and degree of state control over economies. In doing so, we extend the "varieties of capitalism" literature.

The article is organized in five sections. First, we consider what has been described as state capitalism in the existing literature, tracing the evolution of the concept and the phenomenon over time. In the next section, we review how the social sciences have examined state capitalism, and in particular state ownership, generally and in the international business (IB) literature. Next, we present our factor analysis approach to decompose state capitalism into several key dimensions. After that, we demonstrate how the Special Issue articles connect to the main theme of variation in state capitalism and its institutions over time and across countries. We conclude by proposing new directions for future research.

\section{State capitalism: A new phenomenon or a re-incarnation from the past?}

\subsection{The history of state capitalism as a construct}

Polanyi's (1944) classic writings suggest that markets were always state mediated, and once the market shakes off its societal obligations, renewed state intervention takes place, constraining the realm of the market. Other scholars have differentiated state capitalism from capitalism more broadly in that the former "characterize(s) circumstances in which the economic prerogatives of the state exceed those that are merely expected from capitalism's intrinsic properties" (Sperber, 2019; p. 104). In that sense, the contrast between capitalism and state capitalism was the prevalence of social or common ownership of assets, as opposed to private property, and the reliance on state directives and imposed prices, rather than on markets, to make decisions about what to produce and how to sell it. Consequently, "Two constitutive instantiations of state capitalism, common to most writings, are...state's ownership and operation of capitalist enterprises, which is 'state capital, ' and on the other hand, the state's control or influence over the activities of private economic actors, occasionally denoted as 'statism"' (Sperber, 2019; p. 102).

Musacchio and Lazzarini (2014); p.2) emphasize the first dimension, defining state capitalism as "the widespread influence of the government in the economy, either by owning majority or minority equity positions in companies or by providing subsidized credit and/or other privileges to private companies." Other authors have emphasized the second dimension: "a capitalist economic system where the role of the state is dominant in investment, production, and distribution in the economy, through its own undertakings in commercial activities or control over corporations" (Lee, 2018; p. 1).

In part, these different dimensions reflect the rationales behind state intervention. While Polanyi (1944) suggests that state intervention reflects the social problems brought about by market excess, state intervention may open up space for different solutions. The hegemony of neo-liberalism in the policy community since the 1980s-and the assumptions that it represented the most effective or only viable form of capitalism-led to such problems, ushering in a return to income and occupational insecurity in many national contexts (Standing, 2018). However, neo-liberalism was also mutable. Although its ideological foundations suggested a reduction in the state's role to a supervisory one, the neo-liberal order became increasingly dependent on regular state interventions to alleviate the consequences of financial crises, most spectacularly in 2008 and 2020 (Springer, Birch, \& MacLeavy, 2016; Sokol \& Pataccini, 2020). Polanyi's framework may not address the challenges that arise due to the emergence of new, more subtle means of state involvement in markets (Dolfsma \& Grosman, 2019) and the extent to which market interests may benefit from a statist turn. These can include allocating resources to insider interest groups, securing mass compliance through exclusivist nationalism, and paring away democratic institutions (Amable, 2011; Harvey, 2006).

As Adam Smith cautioned, capitalism is associated with strong oligopolistic and monopolistic tendencies (Salvadori \& Signorino, 2014). Governments may seek to challenge monopolies or oligopolies, or shore up their position because of their political power or because they are "too big to fail" (Lambin, 2014). Recently, the latter tendency has become much more common than the former. Finally, the most controversial aspect of state capitalism is how much it generates or destroys value for private interests and society. The analysis of state capitalism has commonly been linked to the inefficiency of state 
economic interventions, largely because of the temptation of politicians to use the state apparatus to generate private benefits (Ades \& Di Tella, 1997). Bremmer (2010) also sees it as "the state...using markets to create wealth that can be directed as political officials see fit...The ultimate motive is not economic (maximizing growth) but political" (p. 4-5). Yet, recent crises have shown that at specific times, markets cannot sustain themselves without large-scale state intervention (Jessop, 2016). Correspondingly, the debate has shifted to how state support should be exercised, and whether private actors gaining state largesse can be trusted to distribute the proceeds wisely (Farhi \& Tirole, 2012; Grimshaw \& Rubery, 2012).

\subsection{Evolution of state capitalism}

The term state capitalism was initially coined by Wilhelm Liebknecht in 1896 to differentiate the socialist state and the state takeover of private companies, such as in the case of railways. That is, he differentiated the state ownership of the means of production from state socialism, which implied the "overall overthrow of the capitalist state and of the entire bourgeois-dominated social structure that upheld it"-mostly after a proletarian revolution (Sperber, 2019; p. 104).

In 1915, Nikolai Bukharin also noted this rise of state ownership of enterprises when he observed "the colossal growth in the economic significance of the state" and that "the war...has caused state-capitalist relations of production to mature rapidly" (cited in Sperber, 2019, p. 104). In fact, in the immediate post-war period, there was a rapid increase in state ownership of enterprises around the world as private firms either failed or were nationalized to prevent large layoffs (Toninelli, 2000). This phenomenon was characterized more by accidental ownership than by an explicit strategy of nationalization and statization (Musacchio \& Lazzarini, 2014).

The rise of larger governments as a consequence of the Great Depression and the consolidation of totalitarian states in the interwar years led to a different conceptualization of state capitalism altogether, from terms like "totalitarian state capitalism" (Pollock, 1941) to a general idea that state capitalism was not only about ownership, but about more state intervention in the economy in general (i.e., more statism) (Polanyi, 1944). The Nazi experience with state control of investment and production became the ultimate example of the model (Overy, 1994). Italy centralized control over a variety of nationalized companies under a state-owned holding company (Amatori \& Colli, 2000). The government of France nationalized the railways, airlines, and a variety of other industries.

The importance of the state in the economy increased after World War II. According to Megginson (2005); p.11), the "economic and industrial mobilization that occurred during World War II dramatically increased the power (and prestige) of national governments as economic managers." Moreover, governments all around the world continued to nationalize industries, including coal, steel, airways, electricity, and gas. State ownership of productive companies probably peaked between the late 1970s and early 1980s (Musacchio \& Lazzarini, 2014).

In the 1970s and 1980s, the issue of efficiency of government ownership became preeminent in academic and policy debates. The economic travails in the Communist bloc raised questions about the efficiency of state ownership, but the two recessions triggered by the oil shocks and stagflation in the 1970s and the 1980s resulted in fiscal crises in many of the Western world's state-owned enterprises (SOEs) (Millward, 2000; Short, 1984). During this period the conceptualization of state capitalism was linked to inefficiency and a threat to businesses (Gwartney, Lawson, \& Block, 1996; Shirley, 1989). The wave of privatizations was largely motivated by this characterization and governments' need for resources to reduce their debt burdens and current expenses (Musacchio \& Lazzarini, 2014).
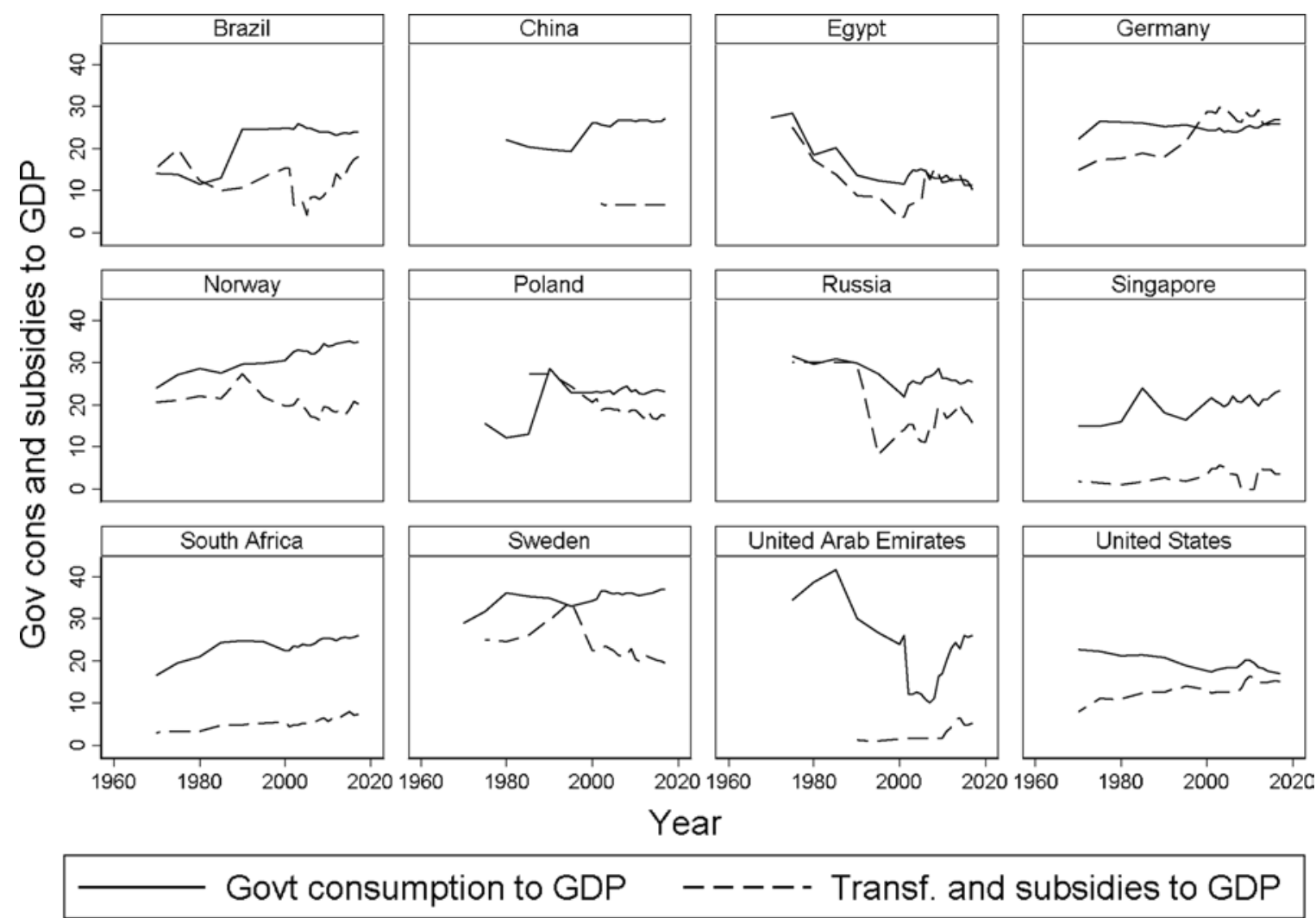

Fig. 1. The Dynamic of Government Consumption and Subsidies to the Private Sector in Selected Countries (1970-2017).

Source: All data from the Fraser Institute, Economic Freedom of the World: 2019 Annual Report, available at fraserinstitute.org, accessed March 15, 2020. 


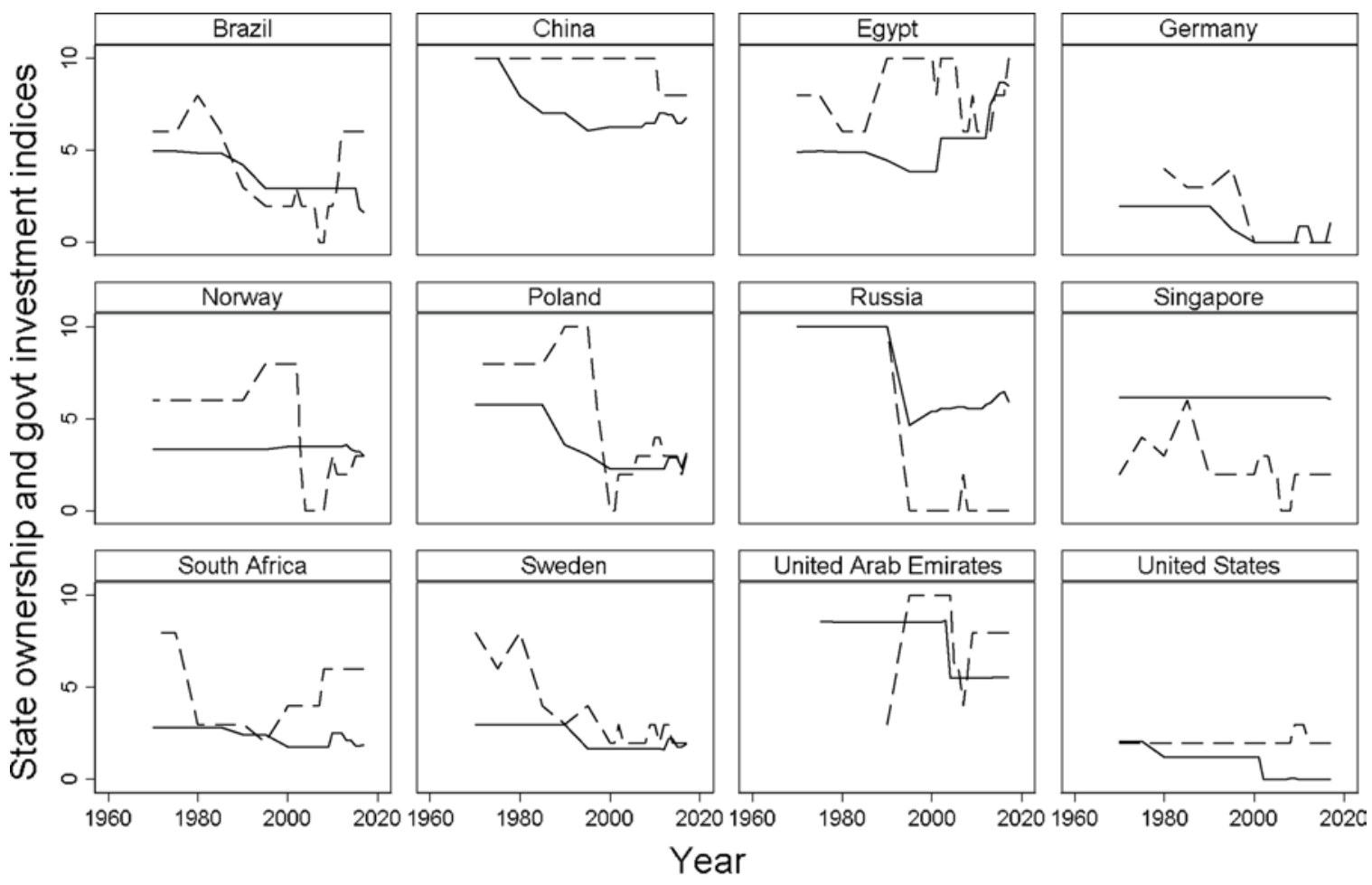

\section{State ownership index - - - - - Gov't investment index}

Fig. 2. The Dynamic of State Ownership and Government Investment Relative to Total Investment in Selected Countries (1970-2017).

Source: All data from the Fraser Institute, Economic Freedom of the World: 2019 Annual Report, available at fraserinstitute.org, accessed March 15, 2020.

Note: The original Fraser Institute's indices of investment are constructed by the Fraser Institute as follows: When government investment share was generally less than $15 \%$ of total investment, countries were given a rating of 10 . When government investment was between $15 \%$ and $20 \%$ of the total, countries received a rating of $8 \ldots$ between $20 \%$ and $25 \% \ldots$ a rating of $6 \ldots$ between $30 \%$ and $40 \% \ldots$ a rating of $4 \ldots$ between $40 \%$ and $50 \% \ldots$ were rated at 2 . A rating of zero was assigned when government investment exceeded $50 \%$. The index of state ownership is equal to (Vi - Vmin) / (Vmax - Vmin) multiplied by 10 . The Vi is the country's state ownership score, while the Vmax and Vmin were set at 2.5 standard deviations above and below the average, respectively. In Fig. 2 we flipped both indices so that 0 represents less state ownership and investment and 10 represents more ownership and investment (all by subtracting 10 and multiplying the result by -1).

\subsection{Recent trends in state capitalism and its conceptualization}

There is wide institutional variation both in the configuration of state capitalist economies and in their level of efficiency. Countries with heavy state presence and ownership of corporations as well as high intervention in markets (statism) can be highly efficient (e.g., Singapore), fairly efficient (e.g., Norway), or highly inefficient (e.g., Italy). As such, scholars have expressed more nuanced views of how states can intervene in the economy to create wealth and promote the domestic industry. Indeed, some have asserted that governments may be better at coordinating actors for the development of new capabilities and at proactive industry diversification and upgrading (Evans, 1995; Lazzarini, 2015; Rodrik, 2004; Aiginger \& Rodrik, 2020). Others have suggested that governments can productively direct financial resources to help firms with financial constraints and untapped opportunities, or to bail out firms that made past bad decisions (Inoue, Lazzarini, \& Musacchio, 2013). Most recently, scholars have noted that governments can use patient capital to promote innovation in SOEs (Jia, Huang, \& Man Zhang, 2019; Lazzarini, Mesquita, Monteiro, \& Musacchio, 2020; Zhou, Gao, \& Zhao, 2017) and develop entrepreneurial activities and new capabilities (Musacchio, Lazzarini, Makhoul, \& Simmons, 2017).

Most countries are arranged along a spectrum of state capitalism where both the intent and extent of state intervention in the economy vary (Ferguson, 2012). All governments intervene in economies for political ends, either via regulations, licensing, taxation, or redistribution of income. All governments employ state ownership to some degree: even in the US, the government owns the land, airports, and mail delivery. Further, the US features a number of oligopolistic industries, such as military hardware and telecommunications (Wood \& Wright, 2015). All governments protect their assets and restrict foreign ownership in some ways and many promote national champions. We conceptualize state capitalism broadly to capture the three main mechanisms of state intervention in the economy: state ownership, statism, and the degree of threat the governments pose to the private market sphere.

In Figs. 1 and 2, we illustrate that there is variation over time in the way governments intervene in the economies and variation across countries in how much governments rely on various tools of intervention. To generate Fig. 1, we used Fraser Institute data to show the variation over time and across countries in the level of government consumption relative to GDP and the amount of transfers and subsidies to the private sector as a percentage of GDP. For Fig. $2,{ }^{1}$ we use the same data to show the variation in the level of state ownership and the importance of government investment relative to total gross capital formation. For illustrative purposes, we select at least one country from each major continent. We also want to contrast similar economies with or without rich oil reserves (e.g. Norway vs. Sweden), as well as contiguous markets that transitioned from communism or not (e.g.

\footnotetext{
${ }^{1}$ For Fig. 2, rather than using the raw data we use the Fraser Institute's indices, which go from 0 to 10 (from more to less state ownership/investment). However, we flip the scale so that 0 means less state ownership/investment and 10 denotes a higher level. This is so that both Figs. 1 and 2 show data that in theory should move in the same direction.
} 
Poland vs. Germany). We add the US, which is not considered a state capitalist economy, to show interesting long-term trends in government consumption and subsidies.

Both Figs. 1 and 2 show that there are variations over time and across countries. We include basic measures of the size of the state to capture the variation over time in statism in developed and emerging markets. In most countries, there is a relatively stable size of the state, but while it is growing in South Africa, it is receding in the UAE and Egypt. In Fig. 2 we show the dynamics of state ownership and investment. In many countries, state ownership and investments decline over the years, indicating a retraction of the state from overall ownership of productive assets in the economy, but there are variations in this reduction and episodic reversals in places like Russia, Brazil, and Egypt. Other countries such as China and Singapore show very stable paths. These cross-national differences demonstrate that state capitalism is more resilient than the privatization literature might assume.

\section{State capitalism in economics, finance, management, and IB scholarship}

\subsection{State ownership and privatization}

Governments have traditionally supported their economies through SOEs in core areas, such as health, defense, and infrastructure (Mühlenkamp, 2015). Even in these areas, governmental support could be outsourced to private firms through public-private partnerships, which would make SOEs cooperate and even compete with the private sector (Foreman-Peck, 2020). In some countries, SOEs were established in areas beyond traditional state functions. Other areas, such as utilities or penal complexes, have been traditionally state-owned, but some governments have experimented with privatization.

Although historically the literature on state ownership focused mostly on the tension between SOEs and purely private firms (Megginson \& Netter, 2001), some studies considered privately owned firms with oligopolistic market positions nurtured and sustained by the government, such as telecommunications in Latin America (Ramamurti, 1996).

The 1980s and 1990s were a period of retrenchment of state capitalism, as communist countries transitioned towards capitalism while governments in advanced economies relaxed regulation and privatized SOEs (Megginson \& Netter, 2001). Each region and the countries within them had somewhat distinct approaches to the sale of state assets to private interests. Megginson and Netter (2001); p. 321) describe privatization as a political, social, and economic policy that is reflected in the "deliberate sale by a government of SOEs or assets to private economic agents." Beginning with the Conservative rule of the UK in 1979 and their auction or sale of many SOEs to private investors, privatization emanated out to more than 100 countries.

A subsequent wave enveloped former Communist countries. Some of these programs were quite controversial because of the lack of transparency and the perception that state monopolies were effectively converted to private ones with little public oversight (Wood \& Wright, 2015). Yet a third wave progressed across Asia and Latin America with some similar concerns. Doh (2000) argued that when privatization is not accompanied by deregulation and market opening, newly privatized SOEs preserve massive advantages of incumbencies that are hard for challengers to break.

The earlier literature on state ownership also focused on the process by which states reduce their ownership and control of corporations via privatization and the variation in outcomes of those processes. One stream of this literature focuses on the overall objectives of privatization (Estrin \& Pelletier, 2018). Another related stream has examined whether and when to privatize, as well as the specific privatization process options (Megginson \& Netter, 2001). Yet another examined the relative effectiveness and efficiency of the privatization process and the new private firms that result (Vickers \& Yarrow, 1993). This research has concluded that privatization must be accompanied by other economic reforms to ensure that the new private firms are properly regulated and that competitive markets are safeguarded (Doh, 2000). Also, relative performance improvement is highly contingent on the privatization process, the legal and regulatory environment post-privatization, and the degree to which markets are opened to competition concurrent with or following privatization (Boubakri \& Cosset, 1998; Megginson, Nash, \& Van, 1994; Dewenter \& Malatesta., 2000).

The second wave of literature on state ownership began in the 2000s. This literature focused on contingencies that either alleviate the negative effects or amplify the positive effects of state control (Grosman, Okhmatovskiy, \& Wright, 2016). Megginson and Liu (2020) examined the relative efficiency of state ownership vs. private ownership in 17 financial economics studies since 2004 and reported that all found that private ownership is more efficient than state ownership. On the other hand, a set of studies in the management literature advanced the "government as strategist" perspective on state ownership, positing that rather than focusing on comparative performance effects, scholars should consider a broader set of objectives, including social and political goals that the governments set for SOEs. Soft budget constraints (Kornai, 1986) - manifested through financial bailouts, state loans, and subsidies-confer on SOEs a higher level of trust from financial investors, resulting in a greater propensity to invest in them. This may also provide SOEs better resilience in times of economic downturn, as in the 2008 financial crisis when some financial institutions were partially nationalized to stay afloat (Bremmer, 2010).

Governments can be patient investors pursuing strategic goals that go beyond profit-maximization (Cuervo-Cazurra, Inkpen, Musacchio, \& Ramaswamy, 2014), allowing SOEs to undertake projects that are initially unprofitable for the sake of a longer-term strategy (Mariotti \& Marzano, 2019). Consequently, some studies found a positive effect of state ownership on performance. Chen, Firth, Xin, and Xu (2009) traced the identities of large shareholders in listed Chinese companies over 1999-2004 and found that the operating efficiency varied across types of controlling shareholders, with SOEs controlled by the central government being the most efficient, private investor-controlled firms the least efficient, and SOEs controlled by local governments falling in the middle. Borisova, Brockman, Salas, and Zagorchev (2012) drew on a sample of $14 \mathrm{EU}$ countries over 2003-08 and found that government intervention is negatively related to governance quality in civil-law countries but positively related in common-law countries.

The most recent wave of literature on state capitalism in the $2010 \mathrm{~s}$ included a variety of new organizational forms. Soon after sovereign wealth funds rose to prominence as global investors in 2007-08, empirical studies appeared examining both the announcement-period stock market returns of target companies and the long-run impact of SWF investment on operating performance (Megginson \& Liu, 2020). Probably the most important political and economic event of the past decade - and the one promoting state capitalism most forcefully-has been the rise of China as the world's second-largest (or by some measures, the largest) economy, leading manufacturer, and exporter. Though the overall level of state ownership in China has been declining for four decades, the largest companies remain state-controlled, and the scale of China's economic growth has raised the global profile and attraction of the state capitalist model (Milhaupt \& Zheng, 2015).

During this period, the biggest innovation in the literature was related to unpacking the types of state ownership-from direct to indirect, from full to minority, from central to local, and depending on investment vehicle (Cuervo-Cazurra et al., 2014; Grosman, Wright, \& Okhmatovskiy, 2016). The literature found that the effect of state ownership largely depends on the type of "state owner." Some studies on China found that abuses of minority shareholders are more common in SOEs controlled by the local government (Jiang, Lee, \& Yue, 2010). Other studies found that support from China's local governments lead to higher firm efficiency relative to firms supported and owned by central government (Cull, Xu, Yang, Zhou, \& Zhu, 2017). Karolyi and Liao 
(2017) found that the motives behind cross-border acquisitions led by government-controlled acquirers differ little from those of corporate acquirers. They also found that short-term market reaction towards deals of government-controlled acquirers is similar to those by corporate acquirers. Newly available data also allowed scholars to explore different outcomes of state ownership such as innovative activities (Jia et al., 2019; Wang, Kafouros, Yi, Hong, \& Ganotakis, 2020, this Special Issue; Zhou et al., 2017; Lazzarini et al., 2020).

Several recent studies examining the performance of SOEs vs. private enterprises also argue that understanding the effect of state ownership requires us to unpack the impact of political institutions and temporary conditions (e.g., financial crises) on SOEs' strategies and performance (Estrin \& Pelletier, 2018; Lazzarini \& Musacchio, 2018; Tihanyi et al., 2019). In the aftermath of the 2008 crisis, renewed growth was somewhat lopsided and left many people poorer and more insecure than before, triggering right-wing populist backlashes (Cumming, Wood, \& Zahra, 2020). There has also been increasing interest in the role of unconventional monetary policy and the uneven effects of quantitative easing and the COVID-19-driven round of bailouts in the US and the UK. Emerging evidence suggests that this may benefit large financial institutions through their over-leveraged and financially frail portfolio companies who qualified for financial relief governments set up to support struggling businesses (Burton \& Fineman, 2020; Wiggens, van der Velde, \& Wigglesworth, 2020).

More recently, some literature has examined the re-nationalization or the creeping expropriation of private interests (Doh \& Ramamurti, 2003; Ramamurti \& Doh, 2004; Wood \& Wright, 2015). These insights, combined with the earlier privatization literature, attest to the dynamic patterns of state ownership of economic assets and the complex interaction of factors that influence whether, when, and how states choose to seize, retain, or relinquish ownership.

\subsection{State capitalism and international expansion: Political, institutional, and competitive environment of home/host countries}

Over the past decade, scholars have increasingly focused on stateowned or directed companies' international expansion and the role of host countries' politics and institutions in that process. This stream emanates, in part, from the growing interest in the expansion of emerging-markets multinationals, many of which are state-owned or controlled.

Research on state capitalism and internationalization from the perspective of host-country institutions emphasizes the challenges SOEs and state-directed firms face as they go abroad. This results, in part, from host-country governments and citizens perceiving foreign government ownership or sustenance of multinationals as illegitimate forms of control over investments and therefore discriminating against them (Cuervo-Cazurra, 2018; Cuervo-Cazurra et al., 2014). This literature also explores how SOEs can overcome this legitimacy deficit through other strategies and signals. Meyer, Ding, Li and Zhang (2014), for instance, demonstrated how Chinese SOEs signaled adherence to the role of law and shareholder protection to compensate for the SOE legitimacy deficit.

Home-country political institutions serve a critical role in where and how SOEs internationalize, including the location for foreign expansion, mode of entry, or the amount of foreign investments (Estrin, Meyer, Nielsen, \& Nielsen, 2016). The extant literature has examined the interaction between home governments and focal firms via state ownership linkages and how these connections, in turn, influence the nature and form of internationalization. For example, Ramamurti and Hillemann (2018) found that SOEs engage in a higher level of internationalization and riskier overseas projects than their private counterparts. The institutional approach is also used in the analysis of the moderating role of institutional quality on the relationship of interest, such as state ownership and internationalization. Mariotti and Marzano (2019) find that the effect of state control on internationalization switches from being negative in liberal market economies to positive in coordinated market economies.

In a subsequent study, Mariotti and Marzano (2020) find that institutional varieties moderate the effect of foreign non-state ownership on the internationalization of SOEs differently. Precisely, the effect of foreign non-state ownership is positive when home countries are closer to liberal market economies - at lower levels of both coordination among institutions and economic actors in pursuing their collective capabilities and government effectiveness. State ownership in state-owned multinationals may insulate them from global institutional pressures, which may lead to negative firm outcomes. A recent stream of the literature distinguishes between minority and majority state ownership, which adds another layer of complexity to institutional moderation (Benito, Rygh, \& Lunnan, 2016; Chen, Musacchio, \& Li, 2019; Grøgaard, Rygh, \& Benito, 2019).

There are two main takeaways from the existing studies about the impact of home- and host-country institutions on SOEs. First, scholarship on state capitalism needs to consider the political environment in which state-owned vehicles operate more explicitly. Recent studies, including Aguilera, Duran, Heugens, Sauerwald, Turturea, and van Essen (2020, this Special Issue), found that political regime influences the effect of state ownership. Shifts in political institutions, political regimes, and ideology were found to lead to substantial transformations of ownership arrangements of internationalizing firms (Carney \& Child, 2013). Political science research has long argued that political institutions are a key determinant of the extent and form of economic and social prosperity (Acemoglu \& Robinson, 2012); similar arguments should be introduced into research on state capitalism.

Second, existing literature on state capitalism in an international context focuses primarily on how the home-country institutions shape the model of state capitalism and internationalization of state assets (Estrin et al., 2016; Grøgaard et al., 2019). More research is warranted on the role of host-country institutions in shaping state capitalism in international settings.

\subsection{Cross-national differences in models of state capitalism}

In some emerging economies, the state's influence on firms' global expansion strategies is all-pervasive. For instance, the Chinese government has been assisting with the internationalization strategies of SOEs but also supporting the internationalization of so-called national champions, as the opening example suggests. In contrast, governments in developed countries usually intervene little in global strategies of their SOEs to the extent that the latter are virtually indistinguishable from private firms (Grøgaard et al., 2019). There is also variation as to how the governments exercise their influence over international expansion strategies, which depends on the type of state-controlled vehicle, the amount of control, and the host country in which the firm is expanding. For instance, Norway has been proactive in formulating restrictions on investment targets for its sovereign wealth fund while leaving the global strategies of SOEs to their own realms. Dominant institutional frameworks within the country of origin affect the scale, scope, and strategies of sovereign wealth funds (Wood \& Wright, 2015). This might range from promoting a more stakeholder-oriented and sustainable version of capitalism abroad to serving as a tool for active economic management at home. The government's use of different economic vehicles and control tools creates a need for coordination mechanisms that can be employed across national contexts.

There is also variation in how the governments sustain ecosystems of oligopolies through public-private partnerships and private finance initiatives. Wood and Wright (2015) found two fundamental issues surrounding these arrangements. First, it is hard to establish the relative worth of public service as a good in its own right vs. the concept of the public as consumers who would benefit from the logic of the market. Second, the functioning of markets is undermined by the tendency for a few firms to dominate the tendering processes, and in some cases, by close linkages between managers and acting or former government 
Table 1

Varieties of State Capitalism - Illustration of Country Fittings.

\begin{tabular}{|c|c|c|c|c|c|c|c|}
\hline 1 & 2 & 3 & 4 & 5 & 6 & 7 & 8 \\
\hline $\begin{array}{l}\text { Interventionist } \\
\text { states }[\mathrm{H}, \mathrm{L}, \mathrm{L}]\end{array}$ & $\begin{array}{l}\text { Interventionist } \\
\text { entrepreneurial } \\
\text { welfare states [H, H, } \\
\mathrm{H}]\end{array}$ & $\begin{array}{l}\text { Interventionist } \\
\text { entrepreneurial } \\
\text { states }[\mathrm{H}, \mathrm{H}, \mathrm{L}]\end{array}$ & $\begin{array}{l}\text { Interventionist } \\
\text { welfare states }[\mathrm{H} \text {, } \\
\mathrm{L}, \mathrm{H}]\end{array}$ & $\begin{array}{l}\text { Market- } \\
\text { oriented } \\
\text { states [L, L, } \\
\text { L] }\end{array}$ & $\begin{array}{l}\text { Welfare } \\
\text { states [L, L, } \\
\mathrm{H}]\end{array}$ & $\begin{array}{l}\text { Entrepreneurial } \\
\text { states [L, H, L] }\end{array}$ & $\begin{array}{l}\text { Entrepreneurial } \\
\text { welfare states } \\
{[\mathrm{L}, \mathrm{H}, \mathrm{H}]}\end{array}$ \\
\hline $\begin{array}{l}\text { Gov Threat: Above } \\
\text { median }\end{array}$ & $\begin{array}{l}\text { Gov Threat: Above } \\
\text { median }\end{array}$ & $\begin{array}{l}\text { Gov Threat: Above } \\
\text { median }\end{array}$ & $\begin{array}{l}\text { Gov Threat: Above } \\
\text { median }\end{array}$ & $\begin{array}{l}\text { Gov Threat: } \\
\text { Below median }\end{array}$ & $\begin{array}{l}\text { Gov Threat: } \\
\text { Below median }\end{array}$ & $\begin{array}{l}\text { Gov Threat: Below } \\
\text { median }\end{array}$ & $\begin{array}{l}\text { Gov Threat: Below } \\
\text { median }\end{array}$ \\
\hline State Own: Low/ & State Own: High & State Own: High & State Own: Low/ & State Own: & State Own: & State Own: High & State Own: High \\
\hline Medium & Statism: High & Statism: Low/ & Medium & Low/Medium & Low/Medium & Statism: Low/ & Statism: High \\
\hline $\begin{array}{l}\text { Statism: Low/ } \\
\text { Medium }\end{array}$ & & Medium & Statism: High & $\begin{array}{l}\text { Statism: Low/ } \\
\text { Medium }\end{array}$ & Statism: High & Medium & \\
\hline Argentina & Greece & Brazil & Croatia & Australia & Austria & Iceland & \\
\hline Bulgaria & & China & Czech Rep. & Canada & Belgium & Malaysia & \\
\hline Colombia & & Hungary & Slovenia & Chile & Denmark & Qatar & \\
\hline India & & Kazakhstan & & Estonia & France & Singapore & \\
\hline Indonesia & & Russia & & Finland & Germany & UAE & \\
\hline Italy & & South Africa & & Hong Kong & Japan & & \\
\hline Jordan & & Thailand & & Ireland & Luxembourg & & \\
\hline Korea, South & & Venezuela & & Israel & Netherlands & & \\
\hline Lithuania & & & & Latvia & Norway & & \\
\hline Mexico & & & & New Zealand & Sweden & & \\
\hline Peru & & & & Spain & & & \\
\hline Philippines & & & & Switzerland & & & \\
\hline Poland & & & & Taiwan & & & \\
\hline Portugal & & & & United & & & \\
\hline Slovak Rep & & & & Kingdom & & & \\
\hline Turkey & & & & United States & & & \\
\hline Ukraine & & & & & & & \\
\hline
\end{tabular}

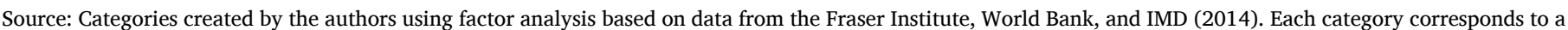

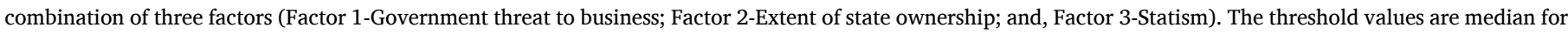

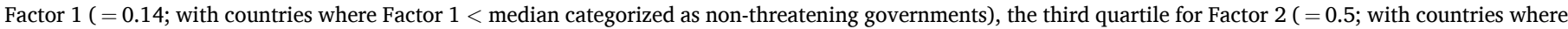

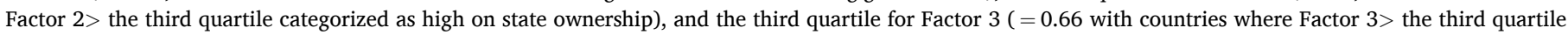
categorized as high on statism).

$\mathrm{L}$ indicates low/medium, while $\mathrm{H}$ indicates a high level of a given state capitalism dimension.

officials creating a complex network of market and nonmarket ties.

\section{Deriving dimensions of state capitalism}

\subsection{State capitalism as a multidimensional phenomenon}

Studies on the variety of capitalism focus on identifying groups of countries that have institutional matrices more conducive to coordination, as opposed to a less interventionist "liberal market" approach (Hall \& Soskice, 2001). More recent work has focused on extending the classification of countries and unpacking other important characteristics of business-government relations. These varieties of capitalism groupings are usually identified using hierarchical clustering in which researchers provide a qualitative description that captures distinctive characteristics of each cluster (e.g., Carney, Estrin, Liang, \& Shapiro, 2019; Fainshmidt, Judge, Aguilera, \& Smith, 2018; Hotho, 2014; Witt et al., 2018). Other researchers proposed continuous composite indicators to overcome the shortcomings of conceptual constructs because varieties also exist among countries of the same category (La Porta, Lopez-de-Silanes, Shleifer, \& Vishny, 1999; Mariotti \& Marzano, 2019; 2020). While we are also interested in the cross-national variety of capitalism, our analytic approach is different. We focus on state capitalism and follow researchers who argue that manifestations of state capitalism can be observed in almost any country (Ferguson, 2012). However, we observe significant cross-national variation in the forms taken and the roles played by state capitalism in different countries.

We consider state capitalism as a multi-dimensional phenomenon, the component constructs of which can be observed as a series of continua along which a particular example of state capitalism can be placed. As such, we identify several key dimensions of state capitalism in which one country can exhibit high values on one dimension and low values on another. In order to derive key dimensions of state capitalism, we use variables characterizing direct state involvement in economic activities-as a customer, owner, creditor, etc.

We do not consider states' performance of basic regulatory functions as a dimension of state capitalism because market-enabling regulation is necessary for the functioning of any capitalist economic system. The inability of the state to regulate business effectively does not indicate "less state capitalism"-it is considered a failure of the state to perform its basic functions. However, our analysis of state capitalist systems does include regulation used by the state for proactive intervention in the production processes and the functioning of the markets. In particular, what we describe as statism, often relies on regulatory instruments (e.g., tariffs, licenses, or tax rebates) to provide support and protection for companies favored by the state, including those with private ownership. We also do not consider characteristics of the political system as a dimension of state capitalism - we treat political systems and economic development as separate domains for comparing countries.

To identify dimensions of state capitalism, we rely on exploratory factor analysis using the principal factor method and orthogonal varimax rotation. As input for this factor analysis, we used seven variables that represent various aspects of state intervention in economic activities: government subsidies, government consumption, government investments, state-owned assets, government effectiveness, government bureaucracy perception, and state ownership perception. This analysis yields three factors with eigenvalues higher than 1 . The factor loadings, the list of countries used, and the factor scores for each country-along with additional details - are reported in Appendix A.

Factor 1 is defined by high loadings of government effectiveness, perception of government bureaucracy as an obstacle, and perception of state ownership as a threat. These factor loadings reflect government quality, independence, and credibility as well as institutional constraints on harmful government interventions (henceforth, we refer to Factor 1 as "Non-threatening government").

Factor 2 is defined by high loadings of state investment to GDP and state ownership of assets. This factor captures state intervention in 


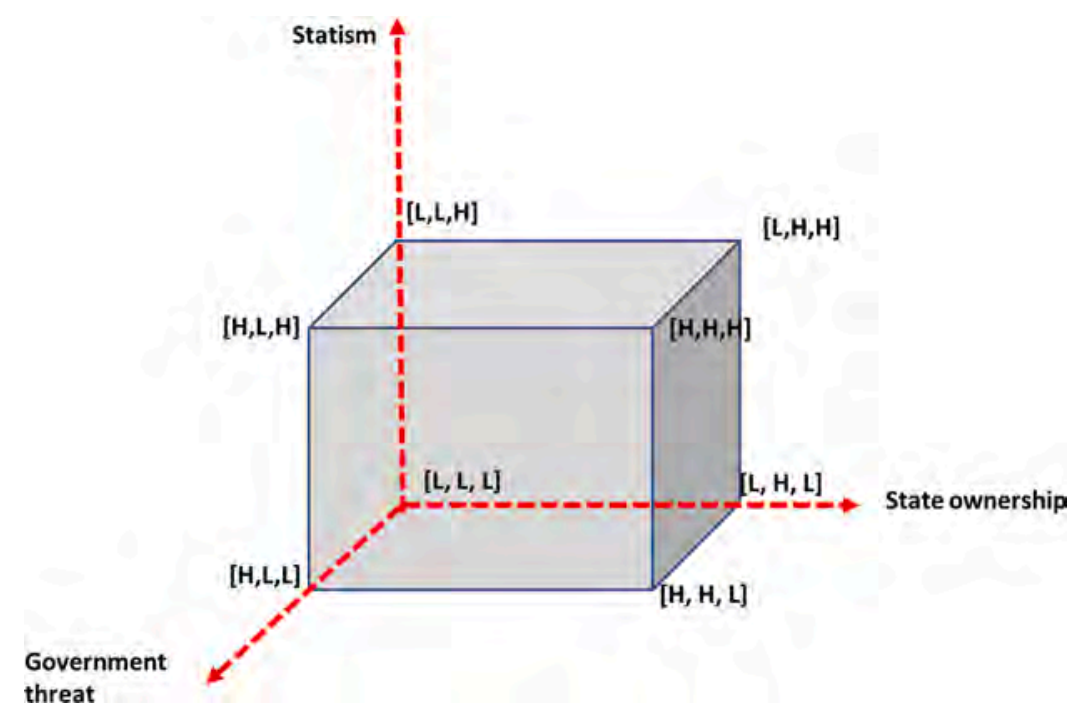

Fig. 3. The Framework for Categorizing Countries Using Three Dimensions of State Capitalism.

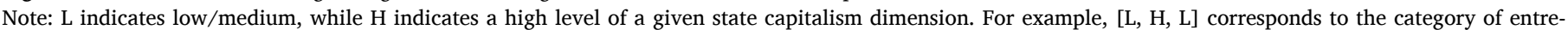
preneurial states, where the threat of government is low/medium, state ownership is high, and statism is low/medium.

economic activity through investments and control of SOEs. This factor captures state ownership broadly (henceforth, we refer to Factor 2 as "State ownership").

Factor 3 is defined by high loadings of state subsidies to GDP and state consumption to GDP. This factor reflects economic interactions between government and business when the government is acting as a consumer or as a source of funds for the business. This factor captures what political science and management literature describes as statism (e.g., Wood \& Wright, 2015). Henceforth, we refer to Factor 3 as "Statism."

\subsection{Interpretation of factor analysis results}

We suggest that these three factors can be considered as three dimensions of state capitalism. "State ownership" and "statism" capture distinct mechanisms that the state can use to intervene in economic activities. The former mechanism is based on the ownership rights that the state can leverage to direct firms toward specific goals determined by the political agenda of the state, which might be very different for developmental, welfare, predatory, and regulatory states (Fainshmidt et al., 2018; Witt \& Redding, 2013). The latter mechanism captured by our "statism" factor is based on the ability of the state to enter into economic transactions with the business. The state may act as a consumer, purchasing companies' products and services, or as a source of funds by providing companies with access to low-interest loans.

The third dimension of state capitalism captured by the "nonthreatening government" factor is important to describe how governments use these tools or mechanisms to intervene in economic activities. There is a striking difference between countries located close to each other on "state ownership" or "statism" dimensions but far from each other on the "non-threatening government" dimension. For example, Singapore and Kazakhstan have almost identical high scores on the "state ownership" factor and very similar low scores on the "statism" factor, indicating that both governments rely heavily on ownership. At the same time, Singapore's score on the "non-threatening government" dimension is much higher than Kazakhstan's, indicating that the Singapore government's economic interventions are perceived as nonthreatening because they happen within well-defined institutional constraints.

\subsection{Varieties of state capitalism: Conceptualization}

Now that we have created three factors that summarize our institutional matrix, we proceed by aggregating them according to how they intersect. For Factor 2 (state ownership) and Factor 3 (statism), we define high values as those above the third quartile threshold $(>=0.50$ and $>=0.66$, respectively). For Factor 1 (non-threatening government), we coded as threatening those countries that have a factor score below the median $(<-0.14)$.

Thus, we ended up with eight initial varieties of state capitalism according to whether they are above or below the median in terms of how threatening the government is (Factor 1 ) and whether they are high (above the third quartile) in terms of state ownership (Factor 2) and statism (Factor 3). We label the categories according to the combination of levels of the three factors (Table 1). The first category is interventionist states, as the above-median government threat factor is signaling government inefficiency and bureaucracy, although both state ownership and statism factors are low/medium. The second category, interventionist entrepreneurial welfare states, are those states where all three factors are high, meaning that the states seek to maximize the profits of government, rather than seeking to maximize the welfare of their constituents (Lal, 1984; Moselle \& Polak, 2001). The third category, interventionist entrepreneurial states, are the states where the government is competing for the assets and "crowding out" the private sector, with high government threat, high state ownership, but low statism (Majumdar, 2009; Van Thang \& Freeman, 2009).

The fourth category is interventionist welfare states, where the level of welfare provided (reflected in the statism factor) is high, but the government threat is also high, while state ownership is low/medium (Algan, Cahuc, \& Sangnier, 2011). The fifth category is market-oriented states since it is characterized by low levels of all three factors. The sixth category is welfare states with high statism and relatively low state ownership and government threat (Ferrera \& Rhodes, 2000). The seventh category is entrepreneurial states with low government threat and statism but high state ownership, indicating that the state is competing with the private sector for business opportunities and ownership of assets (Musacchio, Donovan, Mikati, Sarafa, \& Al Misnad, 2013). Finally, the eighth category is entrepreneurial welfare states with low government threat, high state ownership, and high statism.

Fig. 3 is the conceptualization of varieties of state capitalism along the three dimensions - the level of government threat, state ownership, and statism - which can be used with other sources of data or at another 
Table 2

The Contribution of Each Article in the Special Issue to Varieties of State Capitalism.

\begin{tabular}{|c|c|c|c|c|}
\hline Authors & $\begin{array}{l}\text { State capitalism dimension (s)/ } \\
\text { strands of institutional theory }\end{array}$ & $\begin{array}{l}\text { National } \\
\text { context }\end{array}$ & Method & The role of government \\
\hline $\begin{array}{l}\text { Wang, Kafouros, Yi, Hong, } \\
\text { \& Ganotakis }\end{array}$ & $\begin{array}{l}\text { State ownership } \\
\text { Statism } \\
\text { Institutional economics/ } \\
\text { Institutional polycentrism }\end{array}$ & China & $\begin{array}{l}\text { Longitudinal data } \\
\text { analysis }\end{array}$ & $\begin{array}{l}\text { The role of government viewed through the institutional polycentrism } \\
\text { lens: variations in firm innovativeness and profitability are driven by the } \\
\text { level at which emerging market firms are affiliated with the government }\end{array}$ \\
\hline $\begin{array}{l}\text { Aguilera, Duran, Heugens, } \\
\text { Sauerwald, Turturea, \& } \\
\text { van Essen }\end{array}$ & $\begin{array}{l}\text { State ownership } \\
\text { Institutional economics/ } \\
\text { Institutions-based view }\end{array}$ & $\begin{array}{l}131 \\
\text { countries }\end{array}$ & Meta-analysis & $\begin{array}{l}\text { The role of government ownership is moderately negative, but there is } \\
\text { high heterogeneity across countries. This relationship is driven by } \\
\text { institutions and political orientation; State ownership becoming positive } \\
\text { of performance in countries with right-leaning governments }\end{array}$ \\
\hline Cheung et al., 2020 & $\begin{array}{l}\text { State ownership } \\
\text { Neo-institutionalism/ } \\
\text { Institutional logics }\end{array}$ & Finland & $\begin{array}{l}\text { Historical case } \\
\text { study }\end{array}$ & $\begin{array}{l}\text { Using institutional logics, the role of government and its evolution is } \\
\text { viewed as progressively positive and impacting the decision-making } \\
\text { process of internationalization even though the dominant logic shifts from } \\
\text { the state logic to the market logic }\end{array}$ \\
\hline Cuervo-Cazurra \& Li & $\begin{array}{l}\text { State ownership } \\
\text { Statism } \\
\text { Institutional economics } \\
\text { Neo-institutionalism }\end{array}$ & $\begin{array}{l}\text { Cross- } \\
\text { country }\end{array}$ & $\begin{array}{l}\text { Systematic } \\
\text { content analysis }\end{array}$ & $\begin{array}{l}\text { The contrasting role of government is solved by classifying theories that } \\
\text { suggest a liability of stateness in internationalization (agency, resource } \\
\text { dependence, and neo-institutionalism) and those that suggest an } \\
\text { advantage of stateness (economic development, resource-based view, and } \\
\text { institutional economics) }\end{array}$ \\
\hline
\end{tabular}

point in time. Considering the three dimensions simultaneously is important to correctly characterize the state capitalism profile of a country at a given point in time. We want to emphasize that this representation should be dynamic-the countries are moving from one category to another over time. For instance, with our data measured in 2014, Greece is an interventionist entrepreneurial welfare state, but given that it was borderline on Factor 2, Greece may appear as an interventionist welfare state if the country data is taken for another point in time. However, Greece's recovery, renewed political stability, and good handling of COVID-19 could challenge assumptions of general and terminal inefficiency.

We have not observed any countries in the category of entrepreneurial welfare states, using our data as of 2014, but that does not mean that with a different period of observation, or different dataset, that category would be empty-we believe that Qatar may be moving into that category (Musacchio, Donovan, Mikati, Sarafa, \& Al-Misnad, 2013).

Our categorization of countries is largely different from existing thorough classifications of economic systems and varieties of capitalism. Witt et al. (2018) classify 61 countries into different varieties of capitalism using hierarchical cluster analysis including a large number of development variables. The main difference between our categorizations of state capitalism and the classifications of Witt et al. (2018) is threefold. First, the authors include more variables in their agnostic hierarchical cluster analysis because they are interested in understanding varieties of capitalism, not the role of the state or state intervention per se. Second, the variables they include related to state intervention are less about whether the state or SOEs are a threat than about whether the state intervenes to allocate funds. Finally, their categories are very broad. Our categorization provides a refined institutional picture of how state capitalism works, capturing nuances that cut across traditional geographic categorizations.

When compared with another taxonomy of economic systems described as "varieties of institutional systems" (Fainshmidt et al., 2018), we offer a more fine-grained categorization of state capitalism. While Fainshmidt et al. (2018) consider "state-led" countries as a separate category, our varieties of state capitalism cut across their categories as we focus on "levels" and varieties of state influence. For instance, their category of state-led countries includes Russia, Malaysia, and Argentina, which for us represent three different types of state capitalism.

\subsection{Limitations and potential extensions}

The analysis results are determined by the selection of variables that we used as inputs for our factor analysis. We believe that our results are likely to be reproduced with alternative variables that capture state intervention in economic activity through ownership and consumption or subsidies. However, an important limitation of our analysis is the omission of variables that capture "non-material" aspects of statebusiness relations that allow the state to exercise influence without making investments or entering business transactions with companies. These aspects of state-business relations can be described as coordination that may happen formally or informally. It would also encompass the revolving door between senior politicians, government officials, lobbying outfits, and corporations in the US and the UK, which is often associated with favorable government contracts, concessions to operate outsourced public services, or generous COVID-19 financial bailouts (Sokol \& Pataccini, 2020; Heywood, 2020). Capturing this dimension of "state-business coordination" would be important for explaining cross-national heterogeneity in the functioning of state capitalism. Future research could capture this dimension by tracing the background of directors and managers for current or previous affiliations with the government.

Another important limitation of our data is that it is concentrated in high-, upper-middle-, and lower-middle-income countries. We do not have data to include low-income countries and our sample of lowermiddle-income countries is limited. Yet, this is problematic of most classifications of varieties of capitalism and most of the data on institutions. Since some of the variables we use are constructed with surveys of executives of multinationals who operate in the countries studied, there is a bias in terms of which economies get data-i.e., those in which there is significant foreign direct investment.

\section{Contributions to the Special Issue: Institutional plurality in the service of state capitalism}

Most of the work to date on state capitalism has focused on understanding differences in performance and internationalization behavior, and most of the theoretical literature on the rationale for the behavior of SOEs and state-owned multinationals has focused on typical agency theory models of the privatization literature. That is, we do not know a lot about how other rationales, institutional logics, and motivations come into play to explain why SOEs behave differently than private firms, why they sometimes outcompete their private peers, and why and how they internationalize. This Special Issue focuses on providing answers to those questions.

In this Special Issue, contributors analyze the motives, levels, location choice, and entry methods of SOE internationalization. The studies are heterogeneous in terms of methods, including a historical case study, a systematic literature review, a meta-analysis, and an empirical panel data analysis. Together, they provide us the best evidence to date on the existing literature on state capitalism in the international context 
(Aguilera et al., 2020, this Special Issue; Cuervo-Cazurra \& Li, 2020, this Special Issue) and how to progress it beyond existing studies with newly available data or methods (Wang et al., 2020, this Special Issue; Cheung, Aalto, \& Nevalainen, forthcoming, this Special Issue). Moreover, these studies highlight the importance of political institutions to understanding the behavior of state-owned multinationals and SOEs. Table 2 summarizes the types of state capitalism and firm responses examined in each article included in this Special Issue.

Despite their diversity in topics and methods, the four articles in this Special Issue all have something in common: each advances a strand of institutional theory. However, each adopts a different institutional tradition and builds on a distinct variant of institutional theory. We examine these articles' contributions to the state capitalism literature, emphasizing their theoretical, empirical, and practical implications.

Wang, Kafouros, Yi, Hong, and Ganotakis discuss how affiliation with different government levels influences innovativeness and profitability in China. The authors find that affiliation with higher-level governments enhances firms' innovativeness, whereas affiliation with lower-level governments enhances profitability. Their framework also clarifies how location-specific institutional substitution occurs, indicating that the usefulness of government affiliation for innovativeness depends on how effectively legal institutions protect intellectual property in each region. Wang and colleagues draw from institutional polycentrism, an offshoot from institutional economics, which postulates that organizational outcomes depend on the "confluence" or interdependence of institutions (Ostrom, 2005, 2011). Wang and colleagues show that firms' innovativeness and profitability are shaped differently depending on institutional pressures associated with different levels of government and legal institutions protecting intellectual property rights. Overall, their contribution to the institutional economics approach is to emphasize the interdependences among and configurations of institutions.

Aguilera, Duran, Heugens, Sauerwald, Turturea, and van Essen examine how state ownership impact on firm performance is moderated by the political ideology of the government. The authors find a small negative effect of state ownership on firm performance. They also find that SOEs show stronger performance in countries with right-wing governments and when this ideology is accompanied by a low level of political constraint. Applications of institutional economics in IB typically conceptualize institutions at the country level and are examined independently (Jackson \& Deeg, 2008; 2019). Aguilera et al. show how institutions matter by connecting the political ideology of the government with political institutions - state capacity (effectiveness of a state in implementing policy goals) and political constraint (limitations on a state to implement policy goals)—-to show how political ideology shapes the relationship between state ownership and performance. Specifically, they argue that political ideology and political institutions form interdependent institutional arrangements that highlight the dual function of the government. While governments establish the political institutions that set the political "rules of the game" for all firms, governments as owners are affected by the very same political institutions they help create and sustain. Aguilera and colleagues contribute to institutional economics and the branching-out "institutions-based view" in IB by showing that political institutions are an important, yet often overlooked, factor in how government ideologies impact firm performance.

Cheung, Aalto, and Nevalainen investigate how a shift in dominant institutional logic from state to market logic affected the coevolution of the state governance of SOEs and their internationalization strategy. By conducting a historical case study, the paper shows that a shift in dominant logic impacts decision-making in an SOE through its interaction with the state. Due to this shift in logic, rationales underlying the internationalization of SOEs may change over time. This paper adopts an institutional logics perspective (Friedland \& Alford, 1991; Greve \& Zhang, 2017), a branch of neo-institutionalism. Institutional logics are "supraorganizational historically embedded belief systems that provide rationales for strategic actions, such as internationalization decisions"
(Cheung et al., this Special Issue). Cheung and colleagues contribute to the institutional logics perspective by focusing on logics shifts in a coordinated market economy. The shifts in logics are evidenced by using rigorous historical methods, which have been increasingly adopted in IB but not yet extensively used in studies based on the institutional logics perspective (Buckley, 2009; Jones \& Khanna, 2006). Cheung and colleagues argue that "the dilution of state control is neither required nor sufficient for market logic to overcome state logic; rather, there must be changes in the rationales guiding strategic decision-making."

Cuervo-Cazurra and Li produce a systematic literature review on state-owned multinationals. Their review reveals that SOEs differ from private firms in their internationalization, being motivated by national strategic objectives, selecting more challenging countries, and using acquisitions more intensively. The authors classify the contradicting theories of internationalization into two categories: those that suggest a liability of stateness, and those that promote an advantage of stateness. Cuervo-Cazurra and Li identify 13 studies on SOEs and internationalization that indicate institutional theory as their theoretical basis. The authors conclude that neo-institutionalism with foundations in sociology (DiMaggio \& Powell, 1991; Meyer \& Rowan, 1977) tends to highlight how the costs of state ownership (due to illegitimacy in foreign markets) overwhelm the internationalization benefits it can provide. This illegitimacy tends to lead to lower levels of foreign expansion and investments in host countries, as their governments and consumers are suspicious of and discriminate against firms owned by foreign governments. On the contrary, from an institutional economics viewpoint (North, 1990), SOEs enjoy an advantage of stateness in their internationalization driven by their institutional advantage. SOEs enjoy a higher level of internationalization and an ability to enter more challenging countries thanks to their connection to the government (Benito et al., 2016). Cuervo-Cazurra and Li highlight the complexity of theoretical frameworks based on institutional theory, as the use of one particular branch could lead to a completely different set of predictions relative to another branch. Thus, the authors call for a more contextual approach to theory building. This means that scholars select a strand of the institutional theory they consider more representative of their viewpoint, then deeply explore its assumptions and mechanisms to explain the influence of the government on the behavior of SOEs. Cuervo-Cazurra and Li provide a very clear classification of theoretical predictions of the role of the government in the two strands of institutional theory. Hence, their main contribution to institutional theory is the delineation between the two major strands-institutional economics and neo-institutionalism-in their respective predictions of either an advantage or a liability of stateness.

\section{Discussion, policy implications, and future avenues for research}

\subsection{Discussion and contributions}

A common theme in both the articles in this Special Issue and the preceding literature is that the operation of markets is closely bound up with the state. State capitalism is a pattern of active interventions by the state as both a regulator and market agent; in turn, this may reflect a wide range of rationales from patronage to development. Yet, state capitalism cannot be viewed ahistorically. States may act to establish and nurture market relations, to reshape markets according to prevailing interests, and in response to events. Hence, any manifestation of state capitalism is temporally specific. More challenging question is whether interventions can reset the system or take it to a different place with new tensions and policy solutions (Polanyi, 1944; Wood, 2018). What is evident is that neo-liberalism's proponents and liberal market economies are increasingly associated with non-market solutions, centering on the nationalization of private debt, subsidies to politically powerful sectors, and the active sustenance of private monopolies and oligopolies. It became less a question of whether the state should serve as an active 
economic agent, but rather what particular manifestations of this are more viable and/or desirable, what the consequences are, and whether there are signs of more broadly based interventions disseminating in specific national economies.

There is also a spatial element. It is challenging to disentangle the dynamic relationship between changes in world capitalism and national varieties of state capitalism. However, the changing relationship between Asian economies and Western liberal market economies illustrates the interconnected nature of the two. Although the causes of financialization are complex and multifaceted (Mader, Mertens, \& van der Zwan, 2020), there is little doubt that traditional manufacturing firms in the US and the UK battled to compete on world markets from the 1970s onwards. Part of this was due to active state industrial policies in Japan, and later the Asian tigers. In turn, this led to a change in the focus of corporate activities in the US and the UK: increasingly, there was a turn to what Lazonick and Shin (2019) call predatory value extraction-the extraction of value primarily from liquidating assets and leveraging debt. In turn, this reached unsustainable levels; after 2008, the policy response was quantitative easing. This fueled a new and even more reckless round of borrowing, leading to a further debt crisis in 2020 , followed by a further round of bailouts. These two phenomena highlight how state interventions in sustaining markets may establish a basis of sustained growth (Asian tigers) or simply provide short-term fixes (as with quantitative easing post-2008).

The scope of the state as a market actor is partially molded by past events; this may be because past interventions left particular recipes completely discredited, or because they strengthened specific private interests to such an extent that they were able to drive future state interventions. What is perhaps significant is that since the early 1990s, there has been a proliferation in manifestations of state capitalism. These include increasing (but dynamic) roles for sovereign wealth funds, central banks encroaching into private lending, multinational SOEs, and specific alternative investors (e.g. hedge funds) that enjoy state backing or largesse. It is clear that each of these different types of intervention may yield quite different outcomes for players, a key distinction being between whether they are de facto broad (developmental) or narrowbased (patronage) in scope. With the proliferation of forms of state capitalism has come an increasing divorce between formal ideological justifications and practice. If ideology grounded in realities may help sustain and, hence, embed particular patterns of activity, large gaps between what may be espoused by governments and realities on the ground may lead to policy discontinuity and prioritization of temporary rather than longer-term fixes. In turn, this may lead to external events driving the state's role as a market actor, rather than the state seeking to proactively mold and anticipate events.

\subsection{Future research}

A key question for future research is a dynamic relationship between state and market logics, as Cheung and colleagues highlight in this Special Issue. Even if markets have not been able to sustain themselves without state largesse, this does not necessarily mean subsuming them within the state. For example, states may be captured by specific private interests; historically, this was the preserve of emerging markets, yet some of these tendencies are now evident in some of the most mature economies. In other instances, states have managed to retain and, indeed, extend their influence-leveraging opportunities through their insertion into global markets.

In this Special Issue, Aguilera and colleagues alert us to the relationship between government ideologies and SOE performance. Other work in this Special Issue similarly highlights varieties of statism. If recent research has highlighted the problems of viewing organizational performance solely in terms of short-term returns (Lazonick \& Shin, 2019), then this reopens questions as to how the performance of SOEs might be calibrated and how the balance between social and market performance should be readjusted towards the former. Again, the boundaries of SOEs and private firms occupying oligopolistic market positions whilst providing outsourced services have become blurred (Wood \& Wright, 2013), raising questions as to the trade-off between societal interests and commercial exigencies, and how this plays out according to scope and scale.

Cuervo-Cazurra and Li (2020) this Special Issue) explore two leading strands of institutional analysis and how they may be used to understand the relationship between context, SOEs, and markets, and highlight the need for a deeper contextual focus. Here, we suggest that an influential third strand, comparative capitalism, might further extend the conceptual palette. Further provocative questions include whether legitimation concerns have lessened for large corporations, especially those enjoying oligopolistic market positions and/or those heavily reliant on non-market strategies. In turn, this could lead to greater diversity in terms of legitimation gaps, a ripple effect of legitimation abandonment, or political and/or popular backlashes that may lead to even more stringent standards expected of firms. Again, the relative advantages of state ownership in economic terms in part reflect the ability of national governments to project their power abroad. The present dynamism of the international system, marked by the relative decline of some nations and the revival of others, may make for an even greater heterogeneity or bounded diversity that might merit further investigation.

Finally, Wang and colleagues (2020, this Special Issue) highlight the important phenomena of polycentric institutions, and how this relates to the varying effects and utility of political ties. Here, in addition to complementarity and substitution, future researchers could also draw on theories around institutional layering to understand how institutional regimes seemingly mutate, revive, or simply stop working (or rather narrow to serve a few oligarchic interests). In turn, this might help explain why some state enterprises that should not work seemingly do, and vice versa, and whether their relative performance remains consistent should they extend their activities abroad.

\subsection{Conclusions and policy implications}

Even before the 2020 pandemic, there was a slowdown in global trade (Constantinescu, Mattoo, \& Ruta, 2020). Yet, a feature of this period was that national governments as economic agents were increasingly transnational in their ambitions (Cumming, Filatotchev, Reinecke, \& Wood, 2017). A question emerges as to whether these two tendencies will continue to co-exist, or whether governments will refocus their state capitalist roles towards home markets in order to alleviate the economic consequences of the COVID-19 pandemic. This, when combined with an uneven opening up of the world and restrictions on the movement of people, may lead to a focus on autarchic solutions. Again, sovereign wealth funds are likely to be drawn on by national governments to fund the costs of the pandemic. However, with their war chests swollen with COVID-19 bailouts, US and UK private equity and hedge funds may give renewed attention to foreign takeovers. This is especially so since many domestic firms are already heavily over-borrowed and ill-equipped to shoulder new debt to fund their own takeover. In turn, this has already led to many national economies implementing restrictions on foreign takeovers. Such trends and counter-tendencies open up new space for research on the competing roles of the state as a market regulator and an economic agent, and the contested terrain between the two. Finally, the increased rivalry between the populist-ruled liberal market economies and China is likely to spill over into this domain, with state capitalism being further deployed as a way of serving diplomatic ends by other means, the dynamics of which have only been partially documented.

\section{Acknowledgements}

This article benefited from constructive feedback by Ajai Gaur, Editor-in-Chief, and two anonymous reviewers. We are also grateful for comments and suggestions to Alan Brejnholt, Anthony Brown, Jukka 
Rintamaki, Louise Scholes, Luda Svystunova, Justin Tumlinson, the participants of the Strategic Management Society (SMS) Conference Extension on State Capitalism in 2018, and the Academy of International Business (AIB) conference in 2020. Anna Grosman acknowledges funding by the Society for the Advancement of Management Studies, http:// www.socadms.org.uk/.

\section{Appendix A}

\section{Data and methodology used to derive dimensions of state capitalism}

To identify dimensions of state capitalism we relied on exploratory factor analysis. As input for this factor analysis, we used seven variables that represent various aspects of state intervention in economic activities, as described below:

2 Government subsidies - an index of government subsidies to GDP (2014) from the Fraser Institute Economic Freedom Database ${ }^{2}$.

3 Government consumption - an index of government consumption to GDP (2014) from the Fraser Institute Economic Freedom Database.

Table A1

Factor Loadings.

\begin{tabular}{|c|c|c|c|c|}
\hline Variable & Factor 1 & Factor 2 & Factor 3 & Uniqueness \\
\hline & $\begin{array}{l}\text { (Non-threatening } \\
\text { government) }\end{array}$ & $\begin{array}{l}\text { (State } \\
\text { ownership) }\end{array}$ & (Statism) & \\
\hline $\begin{array}{l}\text { Government } \\
\text { subsidies }\end{array}$ & -0.07 & -0.29 & 0.71 & 0.40 \\
\hline $\begin{array}{l}\text { Government } \\
\text { consumption }\end{array}$ & 0.36 & 0.15 & 0.63 & 0.45 \\
\hline $\begin{array}{l}\text { Government } \\
\text { investments }\end{array}$ & -0.13 & 0.61 & -0.07 & 0.61 \\
\hline $\begin{array}{l}\text { State-owned } \\
\text { assets }\end{array}$ & -0.05 & 0.73 & -0.11 & 0.45 \\
\hline $\begin{array}{l}\text { State ownership } \\
\text { perception }\end{array}$ & 0.69 & -0.11 & 0.04 & 0.49 \\
\hline $\begin{array}{l}\text { Gov. bureaucracy } \\
\text { perception }\end{array}$ & 0.94 & 0.09 & -0.09 & 0.11 \\
\hline $\begin{array}{l}\text { Government } \\
\text { effectiveness }\end{array}$ & 0.86 & -0.22 & 0.29 & 0.14 \\
\hline
\end{tabular}

Source: Estimated by the authors doing factor analysis in Stata using variables based on the following indexes: Government subsidies to GDP (2014), Government consumption to GDP (2014), Government investment to GDP (2014), State ownership of assets (2014) from the Fraser Institute Economic Freedom Database; Government effectiveness perception from the World Bank Worldwide Governance Indicators (2014); Executive perception that "bureaucracy does not hinder business," and Executive perception that "state ownership of enterprises is not a threat to business activities" from the IMD World Competitiveness Yearbook Executive Survey (2014). We display the factor loadings for the three factors with eigenvalues $>1$.

\footnotetext{
${ }^{2}$ We recognize that the Fraser Institute forms part of a cluster of conservative think tanks that received the financial support of specific corporate interests (e. g. the Koch Brothers, ExxonMobil, etc.) (Djelic, 2014), and, as such, its compilation of metrics may suit specific ideological interests or corporate agendas (Dunlap \& McCright, 2011). Hence, we have confined its usage to measures based on official statistics, but, at the same time, recognize that this fails to capture other aspects of statism, for example bailouts for private interests. The World Bank Governance indicators are themselves no strangers to controversy, but they report survey results that, at the least, do capture the opinion of an influential segment of economic interests; even if their perceptions are far removed from objective reality, they would indicate an ease or unease with a particular systemic order, and relative commitment to sustaining or challenging it. At the same time, we would like to make the case that IB research needs to be more aware of the interests behind widely used metrics and that their uncritical usage might help sustain or perpetuate specific agendas.
}

Table A2

Factor Scores for 59 Countries.

\begin{tabular}{|c|c|c|c|c|}
\hline Country & Code & $\begin{array}{l}\text { Factor } 1 \text { (non- } \\
\text { threatening } \\
\text { government) }\end{array}$ & $\begin{array}{l}\text { Factor } 2 \text { (state } \\
\text { ownership) }\end{array}$ & $\begin{array}{l}\text { Factor } 3 \\
\text { (statism) }\end{array}$ \\
\hline Argentina & ARG & -1.09 & 0.29 & 0.02 \\
\hline Australia & AUS & 0.94 & -0.43 & -0.19 \\
\hline Austria & AUT & 0.51 & -0.58 & 0.91 \\
\hline Belgium & BEL & -0.06 & -0.77 & 1.57 \\
\hline Brazil & BRA & -1.05 & 0.64 & -0.11 \\
\hline Bulgaria & BGR & -1.20 & -0.40 & -0.07 \\
\hline Canada & CAN & 0.91 & -0.58 & -0.17 \\
\hline Chile & CHL & 0.38 & -0.83 & -1.10 \\
\hline China & $\mathrm{CHN}$ & -0.86 & 1.93 & 0.15 \\
\hline Colombia & COL & -0.95 & -0.11 & -0.91 \\
\hline Croatia & HRV & -1.25 & -0.15 & 1.09 \\
\hline Czech Rep. & CZE & -0.16 & -0.43 & 0.71 \\
\hline Denmark & DNK & 1.62 & 0.49 & 0.67 \\
\hline Estonia & EST & 0.61 & 0.39 & -0.23 \\
\hline Finland & FIN & 1.76 & 0.44 & 0.64 \\
\hline France & FRA & -0.07 & -0.35 & 1.57 \\
\hline Germany & DEU & 0.28 & -1.46 & 1.01 \\
\hline Greece & GRC & -1.02 & 0.57 & 0.68 \\
\hline Hong Kong & HKG & 1.70 & 0.00 & -1.67 \\
\hline Hungary & HUN & -0.37 & 0.86 & 0.51 \\
\hline Iceland & ISL & 1.18 & 0.71 & -0.33 \\
\hline India & IND & -0.75 & -0.14 & -1.48 \\
\hline Indonesia & IDN & -0.71 & -0.21 & -1.39 \\
\hline Ireland & IRL & 1.00 & -0.45 & 0.02 \\
\hline Israel & ISR & 0.13 & -0.13 & 0.29 \\
\hline Italy & ITA & -1.04 & -1.06 & 0.63 \\
\hline Japan & JPN & 0.30 & -1.16 & 0.89 \\
\hline Jordan & JOR & -0.37 & 0.25 & -0.98 \\
\hline Kazakhstan & KAZ & -0.72 & 1.01 & -0.98 \\
\hline Korea, South & KOR & -0.17 & -0.38 & 0.00 \\
\hline Latvia & LVA & 0.10 & -0.59 & -0.32 \\
\hline Lithuania & LTU & -0.35 & -1.02 & -0.15 \\
\hline Luxembourg & LUX & 0.79 & -0.15 & 1.08 \\
\hline Malaysia & MYS & 0.73 & 1.42 & -0.80 \\
\hline Mexico & MEX & -0.83 & -0.46 & -0.70 \\
\hline Netherlands & NLD & 0.87 & 0.27 & 1.49 \\
\hline New Zealand & NZL & 1.11 & -0.42 & 0.03 \\
\hline Norway & NOR & 0.93 & 0.41 & 0.89 \\
\hline Peru & PER & -1.33 & -0.21 & -1.42 \\
\hline Philippines & PHL & -0.85 & -0.83 & -1.43 \\
\hline Poland & POL & -0.71 & -0.28 & 0.56 \\
\hline Portugal & PRT & -0.39 & -0.64 & 0.45 \\
\hline Qatar & QAT & 0.32 & 1.88 & 0.27 \\
\hline Russia & RUS & -1.48 & 0.72 & 0.62 \\
\hline Singapore & SGP & 2.06 & 1.03 & -0.94 \\
\hline Slovak Rep & SVK & -0.59 & -0.51 & 0.66 \\
\hline Slovenia & SVN & -0.77 & -0.04 & 0.88 \\
\hline South Africa & ZAF & -0.61 & 0.59 & -0.40 \\
\hline Spain & ESP & -0.14 & -0.47 & 0.57 \\
\hline Sweden & SWE & 1.26 & 0.23 & 0.87 \\
\hline Switzerland & CHE & 1.52 & -1.08 & -0.56 \\
\hline Taiwan & TWN & 0.58 & -0.29 & -0.90 \\
\hline Thailand & THA & -0.24 & 0.66 & -0.84 \\
\hline Turkey & TUR & -0.34 & 0.19 & -0.44 \\
\hline UAE & ARE & 1.36 & 1.77 & -0.76 \\
\hline Ukraine & UKR & -1.60 & -0.55 & 0.09 \\
\hline $\begin{array}{l}\text { United } \\
\text { Kingdom }\end{array}$ & GBR & 0.32 & -0.69 & 0.39 \\
\hline United States & USA & 0.59 & -1.10 & -0.49 \\
\hline Venezuela & VEN & -1.81 & 2.17 & -0.46 \\
\hline
\end{tabular}

4 Government investments - an index of government investment to GDP (2014) from the Fraser Institute Economic Freedom Database.

5 State-owned assets - an index of state ownership of assets (2014) from the Fraser Institute Economic Freedom Database.

6 Government effectiveness - an index of government effectiveness from the World Bank Worldwide Governance Indicators (2014) that captures "perceptions of the quality of public services, the quality of the civil service and the degree of its independence from political pressures, the quality of policy formulation and implementation, and the 


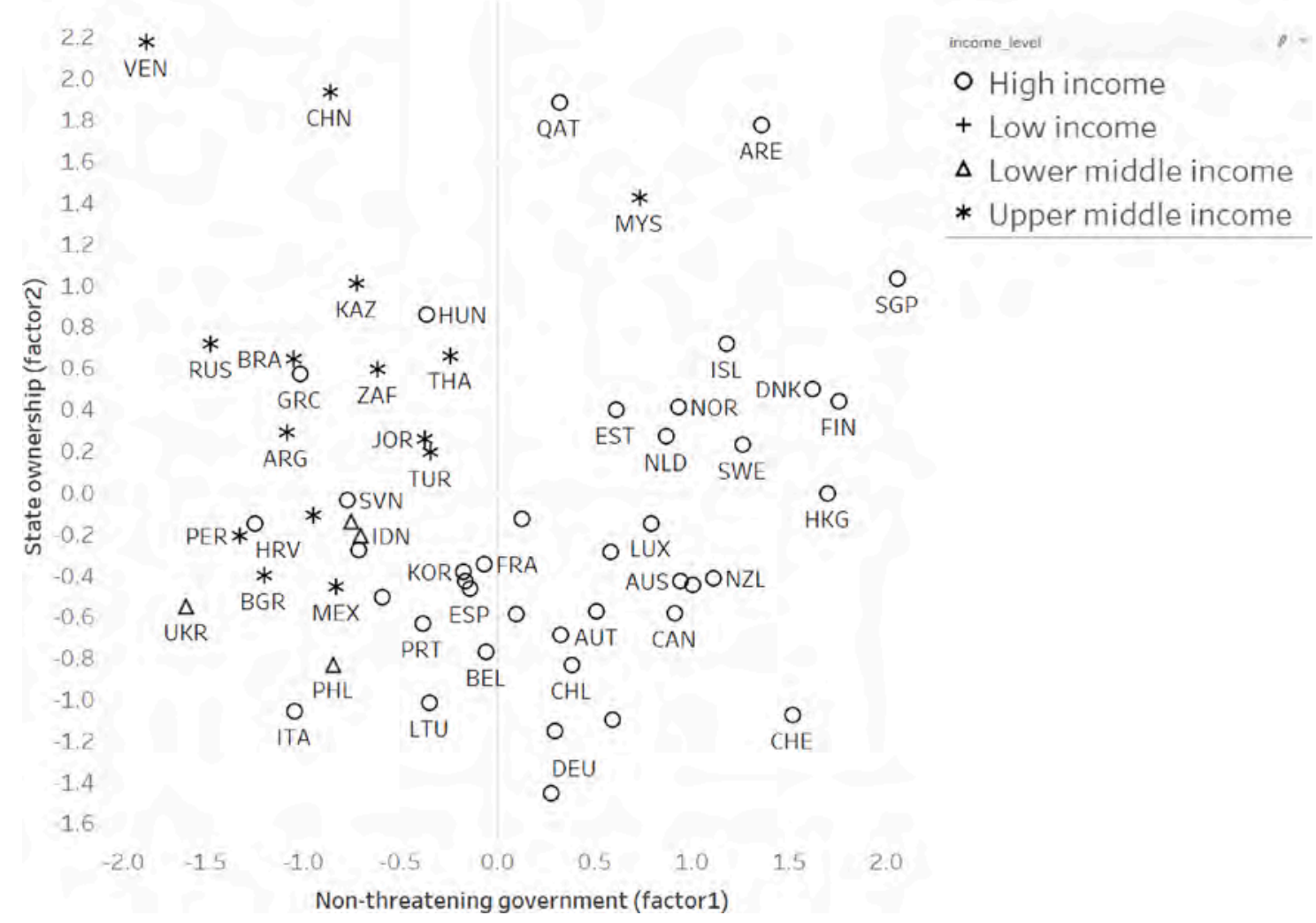

Fig. A1. Scatter Plots of Factor 1 "Non-threatening Government" vs. Factor 2 "State Ownership".

Source: Factor scores derived by the authors from the factor analysis.

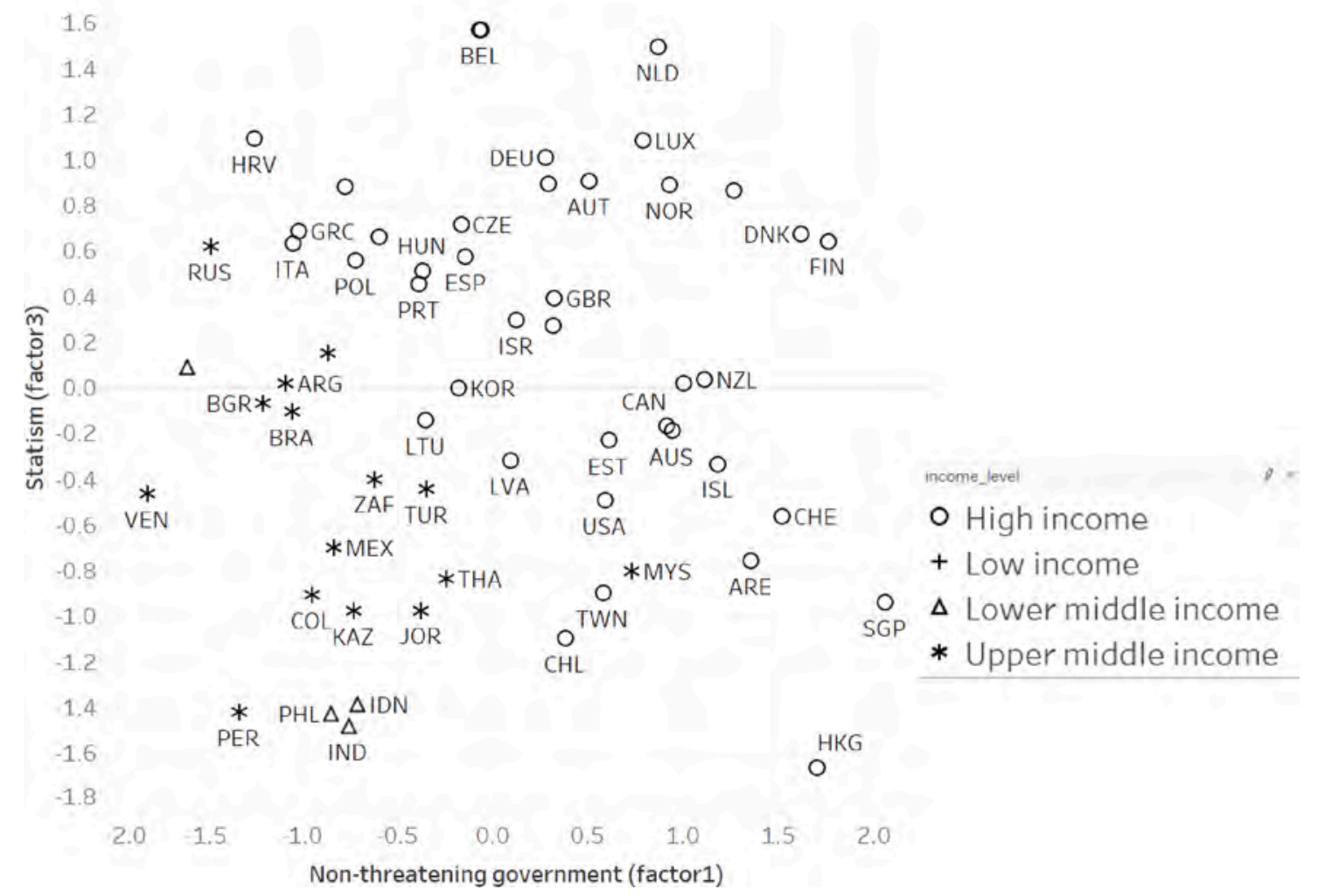

Fig. A2. Scatter Plots of Factor 1 "Non-threatening Government" vs. Factor 3 "Statism". Source: Factor scores derived by the authors from the factor analysis. 
credibility of the government's commitment to such policies" (Kaufmann et al., 2010).

7 Government bureaucracy perception - an index of executive perception from the IMD World Competitiveness Yearbook Executive Survey (2014) reflecting to what extent the respondents agree with a statement that "bureaucracy does not hinder business."

8 State ownership perception - an index of executive perception from the IMD World Competitiveness Yearbook Executive Survey (2014) reflecting to what extent the respondents agree with a statement that "state ownership of enterprises is not a threat to business activities."

Our methodology is inductive and to a large extent agnostic of what dimensions should come out of the factor analysis. While some of our variables are based on the data available for more than 150 countries, the data used for other variables are less comprehensive. All the variables included in our factor analysis were available for the 59 countries listed in Table A2. This sample of 59 countries includes all OECD countries and all major emerging economies from different regions of the world. Most countries not included in our sample either have a small-size economy (e.g., Lichtenstein) or a very low level of economic development (e.g., many African countries). The factor analysis yields the factor loadings reported in Table A1.

Using factor scores calculated for each country, we map the location of countries in the space created by the three factors that we have derived in our analysis (Figs. A1 and A2 and ). Most of the mappings we get from factor analysis are consistent with what we would expect-Singapore, Malaysia, UAE, Qatar, and Northern European countries have relatively large governments that are non-threatening to business, while Venezuela, Russia, Ukraine, Brazil, and Argentina have large state apparatus (both ownership and statism) with more threatening governments for the private sector.

The more interesting cases are those variations in which Eastern European governments are threatening to business and variations that show countries like Italy as having less statism than Scandinavian countries. Thus, we believe our approach takes us beyond simple categorizations of home-country institutions, such as using the level of development or traditional varieties of capitalism to explain state capitalism. The institutional matrix used to separate countries is more complex than that. Also, contrasting authoritarian vs. democratic countries may explain some of the variation, but does not explain why we have authoritarian countries all over the map in both figures.

\section{References}

Acemoglu, D., \& Robinson, J. A. (2012). Why nations fail: The origins of power, prosperity, and poverty. London: Profile Books.

Ades, A., \& Di Tella, R. (1997). National champions and corruption: Some unpleasant interventionist arithmetic. The Economic Journal, 107, 1023-1042.

Aguilera, R. V., Capapé, J., \& Santiso, J. (2016). Sovereign wealth funds: A strategic governance view. The Academy of Management Perspectives, 30(1), 5-23.

Aguilera, R., Duran, P., Heugens, P. P. M. A. R., Sauerwald, S., Turturea, R., \& Van Essen, M. (2020). State ownership, political ideology, and firm performance around the world. Journal of World Business. https://doi.org/10.1016/j.jwb.2020.101113. This Special Issue.

Aiginger, K., \& Rodrik, D. (2020). Rebirth of industrial policy and an agenda for the twenty-first century. Journal of Industry Competition and Trade, 20, 189-207.

Alami, I., \& Dixon, A. D. (2020). State capitalism (s) redux? Theories, tensions, controversies. Competition \& Change, 24(1), 70-94.

Algan, Y., Cahuc, P., \& Sangnier, M. (2011). Efficient and inefficient welfare states. IZA discussion paper series, No.5445.

Amable, B. (2011). Morals and politics in the ideology of neo-liberalism. Socio-economic Review, 9(1), 3-30.

Amatori, F., \& Colli, A. (2000). Corporate governance: The Italian story. Working paper. available at ftp://ns1.ystp.ac.ir/YSTP/1/1/ROOT/DATA/PDF/unclassified/CGITA LY.PDF.

Benito, G. R. G., Rygh, A., \& Lunnan, R. (2016). The benefits of internationalization for state-owned enterprises. Global Strategy Journal, 6(4), 269-288.

Borisova, G., Brockman, P., Salas, J. M., \& Zagorchev, A. (2012). Government ownership and corporate governance: Evidence from the EU. Journal of Banking \& Finance, 36 (11), 2917-2934.
Boubakri, N., \& Cosset, J.-C. (1998). The financial and operating performance of newly privatized firms: Evidence from developing countries. The Journal of Finance, 53(3), 1081-1110.

Bremmer, I. (2010). The end of the free market. Who wins the war between states and corporations? London: Portfolio (Penguin Random House).

Buckley, P. J. (2009). Business history and international business. Business History, 51(3), 307-333.

Burton, K., \& Fineman, J. (2020). Hedge fund managers claiming bailouts as small business. Bloomberg 14 April 2020. Available at: https://www.bloomberg.com/news/article s/2020-04-14/hedge-fund-managers-are-claiming-bailouts-as-small-businesses.

Carney, R., \& Child, T. B. (2013). Changes to the ownership and control of East Asian firms between 1996 and 2008: The primacy of politics. Journal of Financial Economics, 107(2), 494-513.

Carney, M., Estrin, S., Liang, Z., \& Shapiro, D. (2019). National institutional systems, foreign ownership and firm performance: The case of understudied countries. Journal of World Business, 54(4), 244-257.

Chen, G., Firth, M., \& Xu, L. (2009). Does the type of ownership control matter? Evidence from China's listed companies. Journal of Banking \& Finance, 33(1), 171-181.

Chen, V. Z., Musacchio, A., \& Li, S. (2019). A principals-principals perspective of hybrid leviathans: Cross-border acquisitions by state-owned MNEs. Journal of Management, 45(7), 2751-2778.

Cheung, Z., Aalto, E., \& Nevalainen, P. (2020). Institutional logics and the internationalization of a state-owned enterprise: Evaluation of international venture opportunities by Telecom Finland 1987-1998. Journal of World Business. forthcoming. This Special Issue.

Constantinescu, C., Mattoo, A., \& Ruta, M. (2020). The global trade slowdown: Cyclical or structural? The World Bank Economic Review, 34(1), 121-142.

Cuervo-Cazurra, A. (2018). Host country concerns and policies toward state-owned MNEs. Columbia FDI Perspectives. No. 237.

Cuervo-Cazurra, A., \& Li, C. (2020). State ownership and internationalization: The advantage and disadvantage of stateness. Journal of World Business. https://doi.org/ 10.1016/j.jwb.2020.101112. This Special Issue.

Cuervo-Cazurra, A., Inkpen, A., Musacchio, A., \& Ramaswamy, K. (2014). Governments as owners: State-owned multinational companies. Journal of International Business Studies, 45, 919-942.

Cull, R., Xu, L. C., Yang, X., Zhou, L. A., \& Zhu, T. (2017). Market facilitation by local government and firm efficiency: Evidence from China. Journal of Corporate Finance, 42, 460-480.

Cumming, D. J., Wood, G., \& Zahra, S. A. (2020). Human resource management practices in the context of rising right-wing populism. Human Resource Management Journal. https://doi.org/10.1111/1748-8583.12269.

Cumming, D., Filatotchev, I., Reinecke, J., \& Wood, G. (2017). Introducing sovereign wealth funds. In D. Cumming, I. Filatotchev, J. Reinecke, \& G. Wood (Eds.), The Oxford handbook of sovereign wealth funds. Oxford: Oxford University Press.

Dewenter, K., \& Malatesta, P. H. (2000). State-owned and privately-owned firms: An empirical analysis of profitability, leverage, and labour intensity. The American Economic Review, 91(1), 320-334.

DiMaggio, P. J., \& Powell, W. (1991). The new institutionalism in organizational analysis. Chicago: University of Chicago Press.

Djelic, S. (2014). Spreading ideas to change the world: Inventing and institutionalizing the neoliberal think tank. In C. Garsten, \& A. Sorborn (Eds.), Political affair: Bridging markets and politics. Cheltenham: Edward Elger.

Doh, J. P. (2000). Entrepreneurial privatization strategies: Order of entry and local partner collaboration as sources of competitive advantage. The Academy of Management Review, 25(3), 551-572.

Doh, J. P., \& Ramamurti, R. (2003). Reassessing risk in developing country infrastructure. Long Range Planning, 36(4), 337-353.

Dolfsma, W., \& Grosman, A. (2019). State capitalism revisited: A review of emergent forms and developments. Journal of Economic Issues, 53(2), 579-586.

Dunlap, R. E., \& McCright, A. M. (2011). Organized climate change denial. In J. Dryzek, R. Norgaard, \& D. Schlosberg (Eds.), The Oxford handbook of climate change and society (pp. 144-160). Oxford: Oxford University Press.

Estrin, S., \& Pelletier, A. (2018). Privatization in developing countries: what are the lessons of recent experience? The World Bank Research Observer, 33, 65-102.

Estrin, S., Meyer, K. E., Nielsen, B. B., \& Nielsen, S. (2016). Home country institutions and the internationalization of state owned enterprises: A cross-country analysis. Journal of World Business, 51(2), 294-307.

Evans, P. (1995). Embedded autonomy: States and industrial transformation. Princeton: Princeton University Press.

Fainshmidt, S., Judge, W. Q., Aguilera, R. V., \& Smith, A. (2018). Varieties of institutional systems: A contextual taxonomy of understudied countries. Journal of World Business, 53(3), 307-322.

Farhi, E., \& Tirole, J. (2012). Collective moral hazard, maturity mismatch, and systemic bailouts. The American Economic Review, 102(1), 60-93.

Ferguson, N. (2012). We're all state capitalists now. Foreign Policy, 22-25.

Ferrera, M., \& Rhodes, M. (2000). Recasting European welfare states: An introduction. West European Politics, 23(2), 1-10.

Foreman-Peck, J. (2020). Public private partnerships in Britain: Interpreting recent experience. In M. Wright, G. Wood, A. Cuervo-Cazurra, S. Pei, I. Okhmatovskiy, \& A. Grosman (Eds.), The Oxford handbook of state capitalism and the firm. Oxford: Oxford University Press. forthcoming.

Friedland, R., \& Alford, R. (1991). Bringing society back in: Symbols, practices and institutional contradictions. In W. Powell, \& P. Dimaggio (Eds.), The new institutionalism in organizational analysis (pp. 232-263). Chicago, IL, US: University of Chicago Press. 
Greve, H. R., \& Zhang, C. M. (2017). Institutional logics and power sources: Merger and acquisition decisions. The Academy of Management Journal, 60(2), 671-694.

Grimshaw, D., \& Rubery, J. (2012). Reinforcing neoliberalism: Crisis and austerity in the UK. In S. Lehndorff (Ed.), A triumph of failed ideas European models of capitalism in the crisis (pp. 41-58). Brussells: ETUI.

Grøgaard, B., Rygh, A., \& Benito, G. R. (2019). Bringing corporate governance into internalization theory: State ownership and foreign entry strategies. Journal of International Business Studies, 50(8), 1310-1337.

Grosman, A., Wright, M., \& Okhmatovskiy, I. (2016). State control and corporate governance in transition economies: 25 years on from 1989. Corporate Governance an International Review, 24(3), 200-221.

The Guardian (2020). Johnson won't say so, but the real decision about Huawei was made years ago. 28 January 2020. Available at: https://www.theguardian.com/c ommentisfree/2020/jan/28/huawei-security-boris-johnson.

Gwartney, J. D., Lawson, R., \& Block, W. (1996). Economic freedom of the world, 19751995. The Fraser Institute.

Hall, P., \& Soskice, D. (2001). An introduction to varieties of capitalism. In P. Hall, \& D. Soskice (Eds.), Varieties of capitalism: The institutional foundations of comparative advantage. Oxford: Oxford University Press.

Harvey, D. (2006). Neo-Liberalism as creative destruction. Geografiska Annaler Series B, Human Geography, 88(2), 145-158.

Heywood, P. M. (2020). A political approach to corruption. In A. Mungiu-Pippidi, \& P. Heywood (Eds.), A research agenda for studies of corruption (pp. 27-40). Cheltenham: Edward Elgar Publishing.

Hotho, J. J. (2014). From typology to taxonomy: A configurational analysis of national business systems and their explanatory power. Organization Studies, 35(5), 671-702.

Inoue, C. F., Lazzarini, S. G., \& Musacchio, A. (2013). Leviathan as a minority shareholder: Firm-level implications of state equity purchases. The Academy of Management Journal, 56(6), 1775-1801.

Jackson, G., \& Deeg, R. (2008). Comparing capitalisms: Understanding institutional diversity and its implications for international business. Journal of International Business Studies, 39, 540-561.

Jessop, B. (2016). Neo-liberalism, finance-dominated accumulation, and permanent austerity: A cultural political economy perspective. In K. Farnsworth, \& Z. Irving (Eds.), Social policy in times of austerity: Global economic crisis and the New politics of welfare ( $\mathrm{pp} .87-112)$.

Jia, N., Huang, K. G., \& Man Zhang, C. (2019). Public governance, corporate governance, and firm innovation: An examination of state-owned enterprises. The Academy of Management Journal, 62, 220-247.

Jiang, G., Lee, C. M., \& Yue, H. (2010). Tunneling through intercorporate loans: The China experience. Journal of Financial Economics, 98(1), 1-20.

Jones, G., \& Khanna, T. (2006). Bringing history (Back) into international business. Journal of International Business Studies, 37(4), 453-468.

Karolyi, G. A., \& Liao, R. C. (2017). State capitalism's global reach: Evidence from foreign acquisitions by state-owned companies. Journal of Corporate Finance, 42, 367-391.

Kaufmann, D., Kraay, A., \& Mastruzzi, M. (2010). The worldwide governance indicators: Methodology and analytical issues. World Bank Policy Research Working Paper No. 5430. Washington: DC: The World Bank.

Kornai, J. (1986). The soft budget constraint. Kyklos, 39(1), 3-30.

La Porta, R., Lopez-de-Silanes, F., Shleifer, A., \& Vishny, R. (1999). The quality of government. Journal of Law, Economics, \& Organization, 15(1), 222-279.

Lal, D. (1984). The political economy of the predatory state (No. DRD105, p. 1). The World Bank.

Lambin, J. (2014). Rethinking the market economy: New challenges, new ideas, new opportunities. Cham: Springer.

Lazonick, W., \& Shin, J. S. (2019). Predatory value extraction: How the looting of the business corporation became the us norm and how sustainable prosperity can be restored. Oxford: Oxford University Press.

Lazzarini, S. G. (2015). Strategizing by the government: Can industrial policy create firmlevel competitive advantage? Strategic Management Journal, 36, 97-112.

Lazzarini, S. G., \& Musacchio, A. (2018). State ownership reinvented? Explaining performance differences between state-owned and private firms. Corporate Governance an International Review, 26(4), 255-272.

Lazzarini, S. G., \& Musacchio, A. (2020). Leviathan as a partial cure? Opportunities and pitfalls of using the state-owned apparatus to respond to the COVID-19 crisis. SSRN working paper no. 3562406. Available at SSRN: https://ssrn.com/abstract $=3562406$.

Lazzarini, S. G., Mesquita, L., Monteiro, F., \& Musacchio, A. (2020). Leviathan as an inventor: An extended agency model of state-owned vs. Private firm invention in emerging and developed economies. Journal of International Business Studies. https:// doi.org/10.1057/s41267-020-00327-9.

Lee, Y. S. (2018). State capitalism and the law. In M. Wright, G. Wood, A. CuervoCazurra, P. Sun, I. Ohmatovskiy, \& A. Grosman (Eds.), The Oxford handbook of state capitalism and the firm (Forthcoming). SSRN Working Paper available at SSRN: htt ps://ssrn.com/abstract $=3368065$.

Mader, P., Mertens, D., \& van der Zwan, N. (Eds.). (2020). The routledge international handbook of financialization. Abingdon: Routledge.

Majumdar, S. K. (2009). Crowding out! The role of state companies and the dynamics of industrial competitiveness in India. Industrial and Corporate Change, 18(1), 165-207.

Mariotti, S., \& Marzano, R. (2019). Varieties of capitalism and the internationalization of state-owned enterprises. Journal of International Business Studies, 50(5), 669-691.

Mariotti, S., \& Marzano, R. (2020). Relational ownership, institutional context and internationalization of state-owned enterprises. When and how are multinational coowners a plus? Global Strategy Journal. forthcoming.

Megginson, W. L. (2005). The financial economics of privatization. New York: Oxford University Press.
Megginson, W. L., \& Fotak, V. (2020). Government equity investments in coronavirus rescues: Why, how, when?. how, when accessed on 23 April 2020 via. SSRN https ://papers.ssrn.com/sol3/papers.cfm?abstract_id=3561282.

Megginson, W. L., \& Liu, X. (2020). State capitalism and corporate governance. In M. Wright, G. Wood, A. Cuervo-Cazurra, S. Pei, I. Okhmatovskiy, \& A. Grosman (Eds.), The Oxford handbook of state capitalism and the firm. Oxford: Oxford University Press. forthcoming.

Megginson, W. L., \& Netter, J. M. (2001). From state to market: A survey of empircal studies of privatization. Journal of Economic Literature, 39, 321-389.

Megginson, W. L., Nash, R. C., \& Van, R. M. (1994). The financial and operating performance of newly privatized firms: An international empirical analysis. The Journal of Finance, 49(2), 403-452.

Meyer, J. W., \& Rowan, B. (1977). Institutionalized organizations: Formal structure as myth and ceremony. The American Journal of Sociology, 83(2), 340-363.

Meyer, K. E., Ding, Y., Li, J., \& Zhang, H. (2014). Overcoming distrust: How state-owned enterprises adapt their foreign entries to institutional pressures abroad. Journal of International Business Studies, 45(8), 1005-1028.

Milhaupt, C. J., \& Zheng, W. (2015). Reforming China's state-owned enterprises: Institutions, not ownership. In C. J. Milhaupt, \& W. Zheng (Eds.), Regulating the visible hand? The institutional implications of Chinese state capitalism (pp. 175-201). Oxford: Oxford University Press.

Millward, R. (2000). State enterprise in Britain in the twentieth century. In P. A. Toninelli (Ed.), The rise and fall of state-owned enterprie in the Western world (pp. 157-184). Cambridge: Cambridge University Press.

Moselle, B., \& Polak, B. (2001). A model of a predatory state. Journal of Law, Economics, \& Organization, 17(1), 1-33.

Mühlenkamp, H. (2015). From state to market revisited: More empirical evidence on the efficiency of public (and privately-owned) enterprises. Annals of Public and Cooperative Economics, 86, 535-557.

Musacchio, A., \& Lazzarini, S. G. (2014). Reinventing state capitalism. Harvard University Press.

Musacchio, A., Donovan, C., Mikati, S., Sarafa, R., \& Al-Misnad, A. (2013). Qatar: Energy for development. Harvard Business School Case, 714-003.

Musacchio, A., Lazzarini, S., \& Aguilera, R. (2015). New varieties of state capitalism: Strategic and governance implications. The Academy of Management Perspectives, 29 (1), 115-131.

Musacchio, A., Lazzarini, S., Makhoul, P., \& Simmons, E. (2017). The role and impact of development banks. World bank working paper.

Nölke, A. (Ed.). (2014). Multinational corporations from emerging markets: State capitalism 3.0. Cham: Springer.

North, D. C. (1990). Institutions, institutional change and economic performance. Cambridge: Cambridge University Press.

Ostrom, E. (2005). Understanding institutional diversity. Princeton, NJ: Princeton University Press.

Ostrom, E. (2011). Background on the institutional analysis and development framework. Policy Studies Journal, 39(1), 7-27.

Overy, R. J. (1994). War and economy in the third reich. Oxford University Press.

Polanyi, K. (1944). 1957. The great transformation: The political and economic origins of our time (2nd ed.). Boston: Beacon Press.

Pollock, F. (1941). State capitalism: Its possibilities and limitations. Zeitschrift FÃ $1 / 4 r$ Sozialforschung, 9, 200-225.

Ramamurti, R. (Ed.). (1996). Privatizing monopolies: Lessons from the telecommunications and transport sectors in Latin America. Johns Hopkins University Press.

Ramamurti, R., \& Doh, J. (2004). Rethinking foreign infrastructure investment in developing countries. Journal of World Business, 39(2), 151-167.

Ramamurti, R., \& Hillemann, J. (2018). What is "Chinese" about Chinese multinationals? Journal of International Business Studies, 49(1), 34-48.

Reinhart, C. M., \& Rogoff, K. S. (2009). The aftermath of financial crises. The American Economic Review, 99(2), 466-472.

Rodrik, D. (2004). Industrial policy for the twenty-first century. CEPR Discussion Paper 4767, London.

Sallai, D., \& Schnyder, G. (2020). What is "authoritarian" about authoritarian capitalism? The dual erosion of the private-public divide in state-dominated business systems. Business and Society. https://doi.org/0007650319898475.

Salvadori, N., \& Signorino, R. (2014). Adam Smith on monopoly theory. Making good a lacuna. Scottish Journal of Political Economy, 61(2), 178-195.

Shirley, M. M. (1989). The reform of state-owned enterprises:Llessons from world bank lending. Washington D.C: World Bank.

Short, R. P. (1984). The role of public enterprises: An international statistical comparison. In R. H. Floyd, C. S. Gray, \& R. P. Short (Eds.), Public Enterprise in mixed economies: Some macroeconomic aspects (pp. 110-181). Washington D.C: International Monetary Fund.

Sokol, M., \& Pataccini, L. (2020). Winners and losers in coronavirus times: Financialisation, financial chains and emerging economic geographies of the COVID19 pandemic. Tijdschrift Voor Economische En Sociale Geografie, 111(3), 401-415.

Sperber, N. (2019). The many lives of state capitalism: From classical Marxism to freemarket advocacy. History of the Human Sciences, 32, 100-124.

Springer, S., Birch, K., \& MacLeavy, J. (Eds.). (2016). Handbook of neoliberalism. Abingdon: Routledge.

Standing, G. (2018). The precariat: today's transformative class? Development, 61(1-4), $115-121$.

The Economist. (2020). The state in the time of COVID-19. The Economist. March $28^{\text {th }}$.

Tihanyi, L., Aguilera, R. V., Heugens, P., van Essen, M., Sauerwald, S., Duran, P., et al. (2019). State ownership and political connections. Journal of Management, 45(6), 2293-2321. 
Toninelli, P. A. (2000). The rise and fall of public enterprise: The framework. In P. A. Toninelli (Ed.), The rise and fall of public enterprise in the Western world (pp. 3-24). Cambridge: Cambridge University Press.

Van Thang, N., \& Freeman, N. J. (2009). State-owned enterprises in Vietnam: Are they 'crowding out' the private sector? Post-Communist Economies, 21(2), 227-247.

Vickers, J., \& Yarrow, G. (1993). Privatization: An economic analysis. London: MIT Press.

Wang, C., Kafouros, M., Yi, J., Hong, J., \& Ganotakis, P. (2020). The role of government affiliation in explaining firm innovativeness and profitability in emerging countries: Evidence from China. Journal of World Business, 55(3), 101047. This Special Issue.

Wiggens, K., van der Velde, M., \& Wigglesworth, R. (2020). Coronavirus: Private equity's bailout, 14 April Available at: Financial Times https://www.ft.com/content/f7cc82d 7-70b9-40c3-b4a0-815ebc5d99d5.

Witt, M. A., \& Redding, G. (2013). Asian business systems: Institutional comparison, clusters and implications for varieties of capitalism and business systems theory. Socio-economic Review, 11(2), 265-300.
Witt, M. A., Kabbach de Castro, L. R., Amaeshi, K., Mahroum, S., Bohle, D., \& Saez, L. (2018). Mapping the business systems of 61 major economies: A taxonomy and implications for varieties of capitalism and business systems research. Socio-economic Review, 16(1), 5-38.

Wood, G. (2018). The future of the corporation: Economic crisis, long energy transitions and the firm. The Journal of Comparative Economic Studies, 13, 157-169.

Wood, G., \& Wright, D. M. (2013). An age of corporate governance failure?: Financialization and its limits. In M. Wright, D. Siegel, \& K. Keasey (Eds.), The Oxford handbook of corporate governance. Oxford: Oxford University Press.

Wood, G., \& Wright, M. (2015). Corporations and new statism: Trends and research priorities. The Academy of Management Perspectives, 29(2), 271-286.

Zhou, K. Z., Gao, G. Y., \& Zhao, H. (2017). State ownership and firm innovation in China: An integrated view of institutional and efficiency logics. Administrative Science Quarterly, 62(2), 375-404. 